\title{
Histochemical Studies on the Effect of Various Estrogenic Compounds upon the Anterior Lobe of the Pituitary Gland
}

\author{
By
}

\section{Hajime KIMURA}

Department of Obstetrics and Gynecology, School of Medicine, Kanazawa University

(Director : Prof. F. Akasu M.D.)

Uncomfortable side-effects are often observed clinically in the cases of overdosed administration of estrogens as the functions of anterior pituitary were under the influences of estrogen.

The purpose of this article is, therefore, to study histochemical changes of the anterior lobe of the pituitary gland after administration of various kinds of estrogens.

Female, matured and non-parous rats and spayed rats were used as test-animals, and Estradiol benzoate, Estrone, Estrior, Ethinylestradiol, Hexron, Methallenestril and Chlorotrianisene of various concentration were administered to the animals. Experimented histochemical methods are as follows; cytol reaction (so called periodic acid-Schiff reaction), pyronin-methylgreen staining, Gomori's aldehyde-fuchsin staining, Gomori's alkaline phosphatase staining, Ōhara's method for sulfhydryl and haematoxylin-eosin staining. Changes of weights of the pituitary, adrenal glands and ovaries were also followed.

It could be concluded from the obtained results that :

1) Continuous administration of estrogen of small doses stimulated the anterior pituitary function, while the large doses showed reverse effects.

2) Potency of estrogenic effects could be ranked : Estradiol $\doteqdot$ Ethinylestradiol $>$ Hexron, Chlorotrianisene $>$ Estrone $>$ Vallestril.

3) Estriol which has been regarded as an estrogen-metabolite showed some mild stimulating effects on the anterior pituitary gland.

4) Notable changes were observed in the basophilic cells of the anterior pituitary gland after the administration of estrogens.

The PAS-positive substance in these cells might have certain relationships with the anterior pituitary function.

\section{Evaluation of our Modified Methods used for Determination of the Catecholamine Content of Children's Urine}

By

\section{Toshitake ISHII, Toshimichi MATSUMOTO, Hitoo WATANABE}

(From the Department of Pediatrics, Kyushu University Medical Faculty : Prof. Munenori Enjōji)

The total catecholamine content of urine determined chemically by our modification of Euler and Floding's method.

1) The biochemical activity of catecholamine in stored urine was kept up by the addition to the urine of $6 \mathrm{~N}$ sulfuric acid. This acid, which interferes with subsequent procedures when added in 


\title{
各種エストロゲン投与による脳下垂体前葉 細胞の細胞の組織化学的研究
}

\author{
金沢大学医学部産科婦人科学教室（主任 赤須文男教授） \\ 大学院学生木村肇
}

第 1 章 緒

言

幽腺機能は，間脳及び下垂体前葉ホルモン（以下「前葉ホ」之略す）によつて調節が行われているが，一 面，末梢ホルモンは，また逆行性に「前葉木」の分泌を調節し下垂体之性腺とは，いわゆる性中枢の支配下 に，それぞれのホルモンを介して互いに影響を及ぼしあいながら，正常な性活動を維持していることは周知 の上ころである。それゆえホルモン療法を行う際に，使用量の如何によつて，逆効果を来すととがあるの は，すでに Hohlweg')や Meyer ${ }^{2)}$ の報告にもみられたところである。 このさい，エストロゲンの性上位部 逆調節に関しては, 微量の連続投与では, 前葉のゴナドトロピン (以下 $\mathrm{G}$ 之略) の分泌機能を充進せしめ324), かなりの量の連続投与では, 反対にての機能の低下をみるとなす説 ${ }^{5) 6}$ が支配的である. 一面, 衝撃的な大量 投与では，かえつて LH 分泌を促すととも明らかにされた7)10). また Sayers ${ }^{11)}$ は，副腎皮質ホルモンの ACTH に対する関係す略々同様であると述べており，一般に多量のホルモン投与では，前葉機能を抑制し， 少量はむしろ直進させると考えられているが，その作用機序は未だ明らかにされていない，近時臨床面にお いて，天然のむのはむとより，合成されたものも，多数のホルモン剂が用いられる様になり，先の臨床報 告 ${ }^{122}$ １6) も多いが，乙れら両者間に末梢臓器に対する効力に差がある様に，その中枢作用にあ差がありはし ないかというととは，比較検討されなくてはならない，

他面, 前葉の細胞学的研究は1884年に, Flesch 及び Lothringer ${ }^{17)}$ らによつて始められ, 最近では Romeis ${ }^{18)}$, Pearse $^{19)}$ らにより， $\beta, \delta, \varepsilon$ 細胞など数種に分類されている。 また組織化学的研究は， Herlant ${ }^{20)}$ が，前 葉に粘液蛋白質または糖蛋白の存在すること，乙れが $\mathrm{G}$ 之密接な関係があるととなどを報告したことに始ま り, McManus ${ }^{21)}$ が Cytol 反応22) (いわゆる過沃度酸-Schiff 反応, 以下 PAS 之略) を前葉細胞染色㮥用 したことにより，各種ホルモンの産生細胞について多くの知見が得られたが，中であ Purves \& Griesbach ${ }^{23)}$ は, 「前葉小」の中で糖蛋白と考光られる FSH, LH 及び TSH は, それぞれ $\delta$ 緗胞, $\beta$ 細胞から産生され ると推論しており，間脳一下垂体-性腺系の解明と共に，「前葉木」産生の機序が，明らかにされようとして いる。けれどあここには未だ多数の未開地が残されており，乙とに臨床上屡々用いられる各種エストロゲン 製剂の性上位部に対する逆作用の機構，それら相互間の効力の比較などは，明らかにされている面が茥だ少 ないので，私はこれら各種エストロゲン投与時の前葉細胞の变化を，形態学的に特江組織化学的立場加ら実 験を行つたので以下これを報告する。

\section{第 2 章＼cjkstart実験材料並びに実験方法}

\section{第 1 節 実験材料}

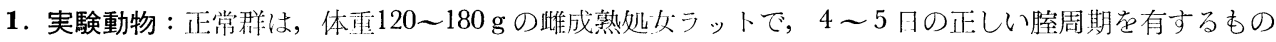
を選び，去勢群としては，上述の条件に命致するラットから両側卵巣剔除を行い，術後24日を経過し，毫周 期が持続的に静止期像を示したものを用い，乙の際飼育環境を一定にするたも，温度，湿度，光度などの外 来刺战に留意し，また飼料む可及的に一定を保つ様につとめた。実験に用いたラット数は，後述の各種エ下 トロゲンの各稀勫段階あたり 3 〜 5 匹とした。

2. 薬剤：使用したエストログンは, Estradiol benzoate（以下 ED 之略), Estrone (以下 EO 之略), 
Estriol (以下ET と略), Ethinylestradiol (以下EED と略), Hexron (以下 Hex と略), Methallenestril (Vallestril, 以下 Vall と略) 及び Chlorotrianisene（以下 TACE と略）の７種類で, そそぞれの滅菌大 豆油による段階稀譒液を使用した。しかして，ED では大豆油 $0.2 \mathrm{ml}$ 中に 0.01，0.02，0.04 (2 i.u.)，0.1， 0.2，1 (50i.u.)，2，20及び1000 (50000i.u.) $\mu \mathrm{g}$ 在含むむのとし，EO，ET は同様大豆油 $0.2 \mathrm{ml}$ 中 $0.04 ， 1$, $1000 \mu \mathrm{g}$ を含む各濃度の屯の在用い，更に EED, Hex, Vall, TACE は，大豆沑 $0.2 \mathrm{ml}$ 中それぞれ 2, 50, 50000i.u. 在含屯各段階稀譒液を使用した。

\section{第 2 節 実験方法}

1.エストロゲン投与㳩：ED，EO 及び ET は，上述各濃度の稀釈液をラットの背部皮下に注射し， EED, Hex, Vall および TACE は，てれぞ狆䃼物用胃内挿管を用いて，経口的に投与した。

2.上述各種類，各濃度のエストロゲンを，正常群では，静止期から始めて 1 日 1 回宛 5 日間にわたり， 皮下または経口的に尰続投与した後，48時間して断頭屠殺し，直ちに下垂体，卵巣，副腎および子宮などを 剔出し, Torsions balance で各蔵器重量を測定し, 下垂体は, 10\%フォルマリン液, Carnoy 液及び冷アセ トン・無水アルコール等量液で固定し， 4 〜 $9 \mu$ のパラィン連続切片を作り，(1)へマトキシリン・エオジ ン染色 (以下 HE と略), (2) PAS 染色 ${ }^{24)}$, (3) ピロニン・メチールグリーン染色 ${ }^{25)}$ (以下 PMG と略), (4) Gomori アルデヒド・フクシン染色 ${ }^{26)}$ (以下 AF と略), (5) Gomori 法によるアルカリ・フォスファタ 一ゼ染色 ${ }^{27}$ (以下 $\mathrm{Al}$-ph と略)，(6) 大原法の $\mathrm{SH}$ 基染色 ${ }^{28)}$ (以下 $\mathrm{SH}$ 染色と略）などを行い，更に一部

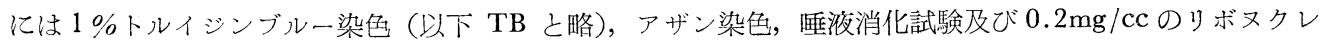
アーゼ消化などを実施し，鏡検した。なお実験方法の性格上，色調判定に重点をおくため，染色時間・至適 温度・至適 $\mathrm{pH}$ ・切片の厚さを一定にするなどの諸点に特に注意し, 実験操作過程をすべて統合調整した。

\section{第 3 章 実 験 成 績}

\section{第 1 節 一般所見}

前葉の腺組織は，微細な血管或は毛細血管を伴う間啠組織によつて，索状或は網状となつて配列してお り，乙の細胞索はかなり緻密に並んだ実啠細胞によつてみたされている。乙の実質細胞の内で，酸好性細胞 （以下 AZ 之略）は，円形または卵円形を呈しており，組胞境界は明瞭である．胞体内には，顆粒の立满す るあのから空胞の混在する屯のに至る迄種々の移行形があり，核は稍々偏心位をとり，核膜は一般に緊張性 を示している。しかし PAS では陽性を示さないが，PMG では胞体に陽性部を認めた。 てれは細胞によ り，核周辺から胞体周辺に至る迄，様々に分布しているが，特に小型円形の細胞に於いて，核周辺に陽性部 が強い. しかし AF では，陽性所見起認めないが， SH 染色では，連続切片で HE のものと比較すると， 茶色の弱い陽性部が認められた。 また Al-ph では，胞体全体が皳漫性にうすい黑褐色を呈した。

塩基好性細胞（以下 $\mathrm{BZ}$ と略）は，正常の前葉細胞中最む大きく，不規則な多角形または卵円形を呈し， 細胞境界は明瞭である。核は多く偏心仿をとり，胞体はPAS $\oplus の$ 微細暗調性顆粒でみたされており，前葉 の前端部に多くまた中心部にも散在性に位置している。更に AF では，前葉中心部に陽性細胞を多く認め

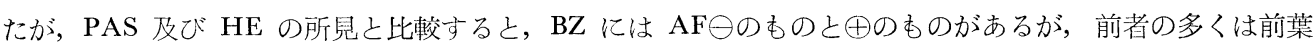
周辺で，衈管の近くに位置する卵円形または多角形の細胞が多く，そのPAS 物質は稍々粗大状を呈し陽 性度も㤝い。乙扎対し後者は，中心部に多く散在し，血管と位蹎的関係がうすく，この数も前者に比して

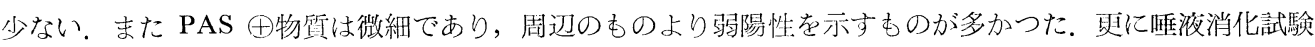
の有無により，PAS 丹物質の出現度をみたが变化なく，また $60 \%$ アルコール及び $50 \%$ アトトン固定の組織 に於いて，PAS甲物質はいづれに於いてもみられなかつた，Al-ph では陽性を殆んど示さないが，PMG ではAZ 程ではないにしても，やはり胞体周辺にピロニン好性の微細構造を認めたが，リボヌクレアーゼに よる消化を行うと，この介物斦は多んど消失し，一部のみはアザン染色を重複すると，消化前と同様に青染 された，更に $\mathrm{SH}$ 染色では，AZ に於けると同様に HE の所見と比較すると，中心部の BZ は卶んど陽性 を早しないが，前葉周辺の BZの胞体に，茶色の弱い陽州:部がみられたが，染色法の関係からその切片は厚 
いので断定は下しにくい.なお TB では，BZ は青染されたが，強いメタクロマジーはみられなかつた。

また主細胞（以下 $\mathrm{HZ}$ 之略）は，胞体に色素好性顆粒を有しないので，殆んど核だけが存在している様 そみえる小さい細胞であるが，その数は前二者に較心゙て多く，屢々これらの細胞との間に移行形がみられ た. 細胞境界は不明瞭であり, 各種類の染色法によつて屯, 胞体には顕著な变化在認めにくい. 核も染色州:

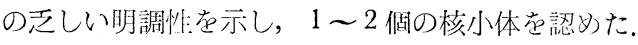

\section{第 2 節 性周期による変化}

\section{1. 下垂体前葉の組織化学的所見}

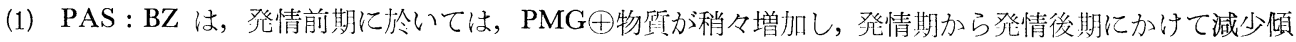

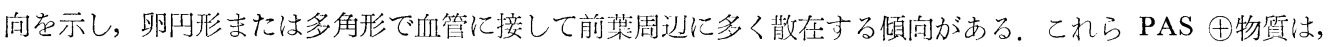
静止期及び発情前期では，顆粒状を呈し稍々粗大であるが，発情期のそれは，全周期の中で最も微細で染色 度も弱汃て(

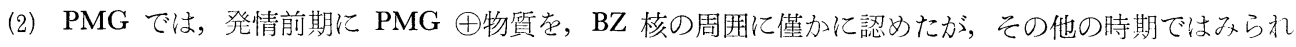
なかつた。また $\mathrm{AZ}$ 及び $\mathrm{HZ}$ については，性周期に伴う変化はみられなかつた。

（3） AF では，前葉中心部に散在する PAS 細胞に陽性を認めたが，周期的変化は見饳せず，しか屯周 辺部には， $\mathrm{AF} \oplus$ 細胞は見出しえなかつた。

（4）Al-ph は，AZ に褐色の陽性部を認めたが，BZ には陽性像は殆んどみられず，周期的変化す見出し えなかつた。

（5） SH 染色では，前葉周辺に弱い陽性部を認めたが，周期的変化はみられなかつた。

2. 各臓器の重量変化：性周期に伴い，下垂体，副腎，卵巣及び子宮重量は，表 1 の様な变動を示し，下 垂体及び副腎は, 発情前期に増加の傾向を示したが，推計学的に有意の差は認め難かつた。しかし卵巣及び 子宮の重量は，発情期に最大值を示し，静止期のそれに較べて，それぞれ $21.5 \% ， 30.9 \% の$ 増大を認めた。

表 1 性周期に伴う各臟器の重量変化

\begin{tabular}{|c|c|c|c|c|}
\hline 性＼cjkstart腺＼cjkstart藏＼cjkstart器 & 静 止 期 & 発 情 前 期 & 発＼cjkstart情 & 発 情 後 期 \\
\hline 下垂体重量（mg） & $7.16 \pm 1.30$ & $8.08 \pm 0.46$ & $6.50 \pm 1.50$ & $5.50 \pm 1.50$ \\
\hline 副腎重量 (II) & $23.00 \pm 1.52$ & $24.50 \pm 3.50$ & $24.00 \pm 2.44$ & $20.00 \pm 2.44$ \\
\hline 卵巣重量 ("I) & $45.00 \pm 5.00$ & $43.50 \pm 1.50$ & $54.50 \pm 2.50$ & $49.66 \pm 6.73$ \\
\hline 子宮重量 (II) & $277.50 \pm 27.15$ & $331.80 \pm 20.19$ & $363.30 \pm 46.70$ & $261.70 \pm 11.17$ \\
\hline
\end{tabular}

註＼cjkstart数字は平均重量士標準誤差以下同様に記載

\section{第 3 節 去勢による影響}

\section{1. 組織化学的変化}

（1）去勢後20日：PAS $\oplus の \mathrm{BZ}$ は，その数，細胞の大きさ及び陽性度が，対照に比して増加を示し，特 に前葉周辽部の毛細血管に沿つた細胞に湴くみられた。このさい毛細血管腔は拡大し，充向像を示してい

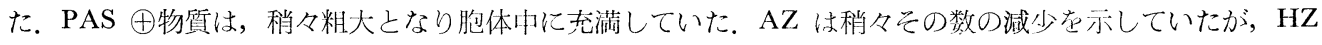
には，著変を見出しえなかつた。

（2）去勢後23日：BZ，AZ 及び $\mathrm{HZ}$ の各細胞は，いづれあ(1)に於ける变化が更に流められた感があり，

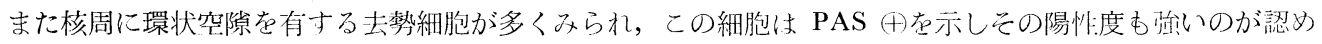
られた。

（3）去勢後30日：PAS (細胞は，更に胞体及び陽吽度が大となり，陽吽物啠は粗大顆粒状を号していた。 また去勢細胞は数多く前葉全域にみられ，核の周用に大きな環状空胞を有し，核は偏心位をとり，毛細血管 は充血を示し，㞗々洞様に拡大しているのがるら狆た。な打 $\mathrm{AZ}$ は，特に变化を示さなかつたが，HZは 
減数を示した（写真 $3 ， 16$ )。

（4）去勢後40日：PAS $\oplus$ 細胞は, 著明に増加し, 特に中心部に多く, これらの陽性物質は, 粗大顆粒状 を呈していたが，乙れに反し周辺部の陽性物質は，稍々微細状を示していた，去勢細胞も数が增加し，その 核周の空胞は広く，ために核は偏在し，核周は厝々明調性を示し，この核の一端に肥大したゴルヂ装置の陰 影像がみられた。 AZ には著変がなかつたが，HZ は更に減数していた。

（5）去勢後60日：PAS $\oplus$ 細胞は，肥大して卵円形を示すものが多く，大きな空胞を有する去勢細胞も認 められ，また印環細胞と思われる去勢細胞屯出現し，その空胞中にコロイド様物質が含有され，胞体はPAS 陽性度が強く, 特にその周辺増量していた。 血管腔は拡大し, 洞様を呈するすのが多く, 充血像か沙い。 その他，AZ 及び HZ では，去勢後40日の所見に比し，著差を認めえなかつた（写真 4 ）.

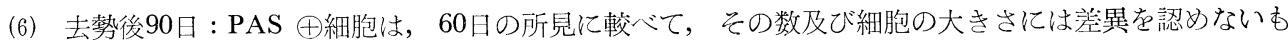
のが多かつたが，中心部の PAS 丹細胞の顆粒は粗大となり，その空胞の大きさ屯減弱しており，崩壊像ら しいものも認めえた。核は一般に不明暸となり，濃縮像を示し，印環細胞も出現していた。間質における血

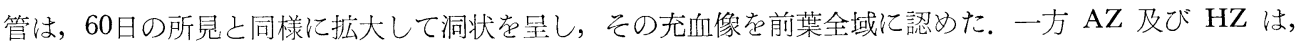
去勢像60日の所見に比して, 差異は殆んどみられなかつた。

2. 各臟器の重量変化 : 去勢によつて下重体重量は, 表 2 及び図 1 の如く変化した. 即ち体重 $100 \mathrm{~g}$ 当り

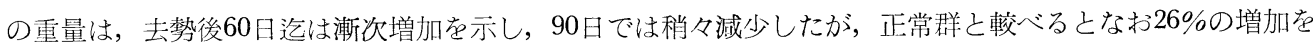
示していた，乙の間，去勢後60日で最大值を示し， $7.4 \mathrm{mg}$ で正常群のそれに較べて約 $3 \mathrm{mg}$ の増大を旺して いた。副腎重量は, 去勢後 20 日では, 体重 $100 \mathrm{~g}$ 当りの重量は, 平均 $32 \mathrm{mg}$ 上最大値を示し, 明らかに正常群

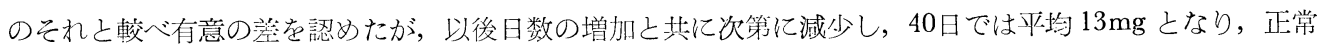
群よりもむしろ整量を示した。更にそれ以後は，僅かに増量傾向を示したが，著変は認められなかつた。

表 2 去勢による下垂体, 副腎の重量変化

\begin{tabular}{|c|c|c|c|c|c|c|c|}
\hline 圭勢後日数 & 照 & 20 & 23 & 30 & 40 & 60 & 90 \\
\hline 下垂体重量(mg) & $7.25 \pm 0.25$ & $6.00 \pm 0.62$ & $6.51 \pm 2.45$ & $8.50 \pm 0.41$ & $7.50 \pm 0.73$ & $16.10 \pm 0.89$ & $11.00 \pm 1.80$ \\
\hline 副腎重量（"I） & $24.50 \pm 0.50$ & $34.50 \pm 1.50$ & $32.50 \pm 1.44$ & $31.50 \pm 0.68$ & $27.70 \pm 3.19$ & $39.40 \pm 0.32$ & $43.00 \pm 1.54$ \\
\hline
\end{tabular}

図 1 去勢による下垂体，副腎の重量 $(\mathrm{mg}) /$ 体重 $100 \mathrm{~g}$

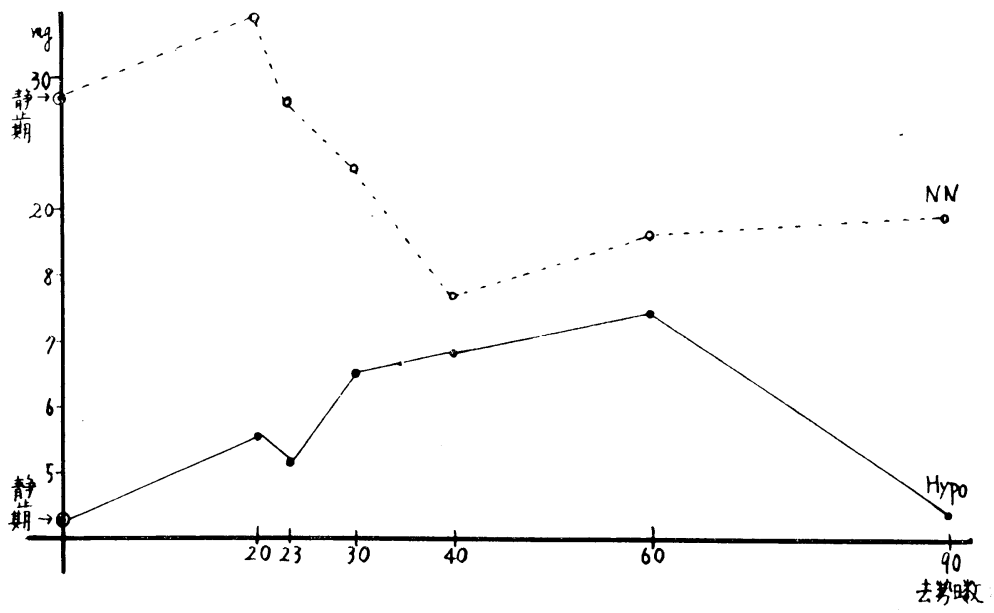




\section{3. 小括}

性周期に伴う性腺の変動について, $\mathrm{Hill}^{29)}, \mathrm{Wolf} \mathrm{e}^{30)}$ 及び松田 ${ }^{31)}{ }^{32)}$ らは, その重量が周期的にあ変化する と述べており，一力下垂体に於いても伊藤 ${ }^{33}$ は，静止期に BZ の数が増加する事を観察し，Catchpole ${ }^{34)}$ す, 同様な所見を報告し，加えて組織化学的研究により，PAS 物質が発情前期に多くみられた事から， G, 殊に FSH との関係を推察している。私の実験において，前葉の組織化学的所見は，軽度ではあるが発情前

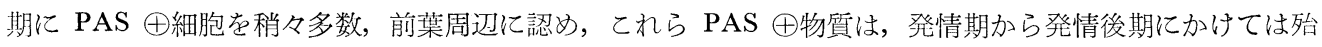
んぞ消失しているのを知つた，乙れに対し下重体重量は，平行的に増減の傾向を示したが，有意の変化は示 さず，卵巣及び子宮の重量は，発情期に最大值を示し，周期的変化を示した．次に，去勢後の下垂体の変化 をみると，去勢による BZ の変化は著しく，特に去勢後60日で著明であつた，即ち胞体内の PAS 丹物澌 も多量となり, 粗大顆粒状を呈し, これにつれて重量増加も認められた. 去勢洔には, Gの量が増加する事

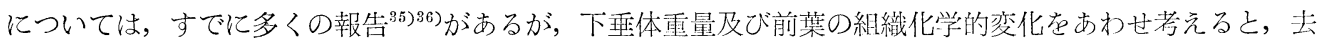
勢により前葉の分泌機能は充進しており，乙のさい特異的に現われる去勢細胞は，乙の機能无進と密接な関

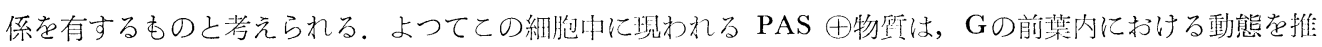
測する有力な一つの示標と屯考えられるであろう。さらに去勢後の副婜車量を考えると, 去勢後20日迄は次 第に増加するが，以後滅少を示し，40日では正常群のそれよりも低下しており，その後は著変を示さなかつ た，これは，去勢直後は性腺の代償を副婜が学さが，一定期間（20日）以後では，漸減して一定值に近づい

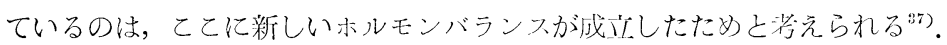

\section{第 4 節＼cjkstart各種エストロゲン投与が下垂体，副腎及び卵宩に及ぼす影響}

\section{第 1 項 去勢群}

1. 対照(去勢後24日目からェストロゲン油淮の泪滩のみの投与を行つたもの)：前葉に於いて，卵円形の

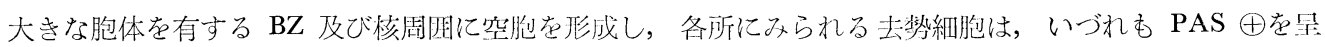

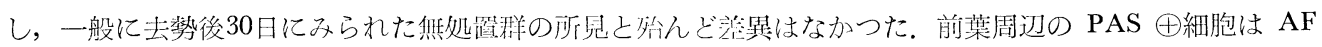

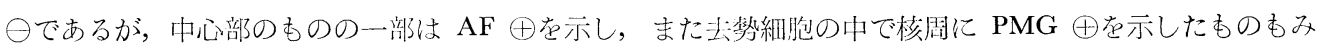
たが，その陽州度は微弱であつた，SH 染色では，胞体は满漫性に弱陽性を示していた。

2. 天然エストロゲン投与群

(1) ED 投与群

(i) 下重体に於ける変化

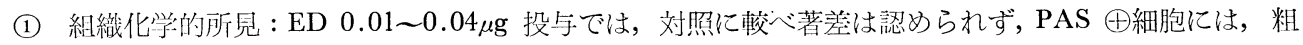
大な陽性顆粒がみられた。 $\mathrm{AZ}$ 及び $\mathrm{HZ}$ も同様に著栄を示さなかつた(写真 5，20).

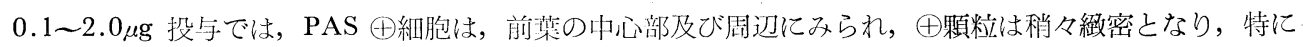

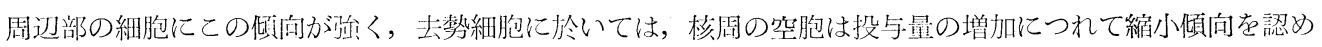
た。 これらの細胞核は偏在し，ゴルヂ装䓟の陰影は大となつて核に接しているが，血管に接する陽性細胞に

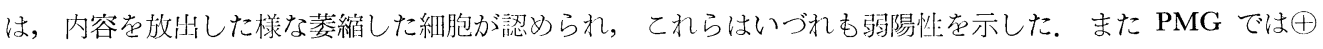
物淎を認めた (写真 6 ).

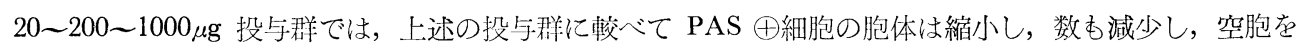

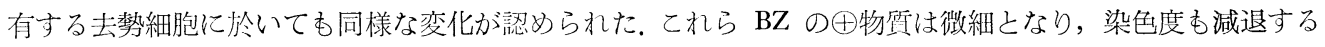
が，細胞間隙は広功た（写真 7, 21).

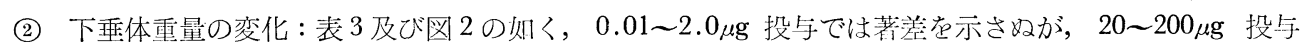
時に増大し，対照群に比し24〜28\%増大していた。 また $1000 \mu \mathrm{g}$ 投与㭙には，実測值では更に肥大傾问を示 しているが, 体重 $100 \mathrm{~g}$ 当りの重量は逆に減少を認めた.

(ii）副腎重量の変化：表 4 の如く $0.4 \mu \mathrm{g}$ 以下の少量投与によつて対照の 10 ～30\%の增加を認めたが， $1 \sim 2 \mu \mathrm{g}$ 投与時には稍々減少を示した. また $20 \mu \mathrm{g}$ 投与では副腎重量は最高值を示したが，それ以上の投 与量では再び減少を示した。 
表 3 各種各濃度エストロゲン投与による去勢ラットの下垂体重量 $(\mathrm{mg})$ の変化

\begin{tabular}{c|c|c|c}
\hline \hline \multirow{2}{*}{$\begin{array}{c}\text { 投与エトロゲン量 } \\
\mu \mathrm{g} / \text { 日 }\end{array}$} & \multicolumn{3}{|c}{ エストロゲンの種類 } \\
\cline { 2 - 4 } & $\mathrm{ED}$ & $\mathrm{EO}$ & $\mathrm{ET}$ \\
\hline $0 \quad$ (対照) & \multicolumn{3}{|c}{$7.25 \pm 0.60$} \\
\hline 0.01 & $8.05 \pm 0.95$ & & \\
0.02 & $7.40 \pm 0.79$ & & \\
0.04 & $8.50 \pm 0.50$ & $7.00 \pm 0.36$ & $8.50 \pm 0.50$ \\
0.1 & $8.25 \pm 0.78$ & & \\
0.2 & $7.50 \pm 1.05$ & & \\
0.4 & $8.95 \pm 0.69$ & & \\
1 & $8.50 \pm 0.79$ & $8.00 \pm 1.00$ & \\
2 & $8.25 \pm 0.68$ & & $11.00 \pm 1.00$ \\
20 & $9.25 \pm 1.25$ & & \\
200 & $9.00 \pm 1.04$ & & \\
1000 & $9.50 \pm 0.29$ & $10.75 \pm 0.25$ & \\
\hline
\end{tabular}

図 2 各種各濃度エストロゲン投与による垫ラットの下垂体重量( $\mathrm{mg}$ )/ 体重 $100 \mathrm{~g}$

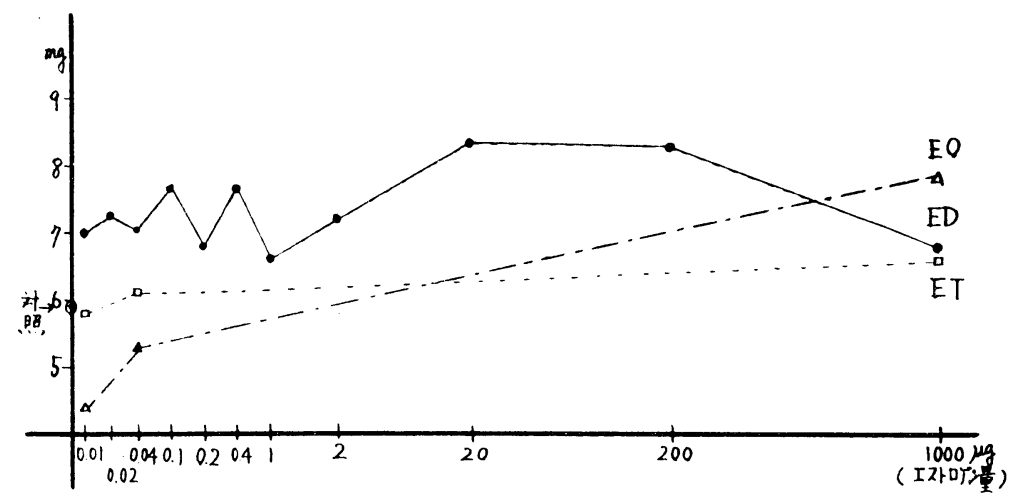

表 4 各種各濃度エストロゲン投与による去勢ラットの副腎重量 $(\mathrm{mg})$ 変化

\begin{tabular}{c|c|c|c}
\hline \multirow{2}{*}{$\begin{array}{c}\text { 投与エストゲン量 } \\
\mu \mathrm{g} / \text { 日 }\end{array}$} & \multicolumn{3}{|c}{ エストロゲンの種類 } \\
\cline { 2 - 4 } & $\mathrm{ED}$ & $\mathrm{EO}$ & $\mathrm{ET}$ \\
\hline $0 \quad$ (対照) & \multicolumn{3}{|c}{$30.66 \pm 2.06$} \\
\hline 0.01 & $38.00 \pm 1.00$ & \\
0.02 & $39.50 \pm 0.50$ & & \\
0.04 & $40.00 \pm 1.50$ & $20.00 \pm 2.31$ & $24.50 \pm 4.50$ \\
0.1 & $33.00 \pm 3.00$ & & \\
0.2 & $34.01 \pm 3.70$ & & \\
0.4 & $40.50 \pm 1.50$ & & \\
1 & $31.00 \pm 3.00$ & $25.10 \pm 3.32$ & \\
2 & $30.00 \pm 4.00$ & & 3.47 \\
20 & $42.00 \pm 3.00$ & & \\
200 & $36.10 \pm 3.05$ & & \\
1000 & $39.50 \pm 6.50$ & $34.80 \pm 2.23$ & 3.20 \\
\hline
\end{tabular}


(2) $\mathrm{EO}$ 投与群

(i) 下垂体に於ける変化

(1) 前葉の組織化学的变化：EO $0.04 \mu \mathrm{g}$ 投与では，PAS $\oplus$ 細胞の大きさ及び数は多いが，対照群に較へ て著差はみられなかつた。

$1 \mu \mathrm{g}$ 投与では，PAS 陽性度は，前者と同様に強く，丹物質は前者より粗大顆粒状を呈し，胞体内に充満 しており，胞体周辺部に特に多く集まつていた。毛細血管は充血して広い腔を有していた。 また PMG $\oplus$

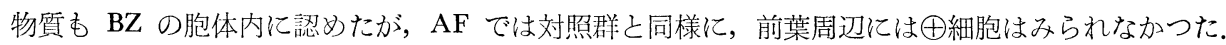

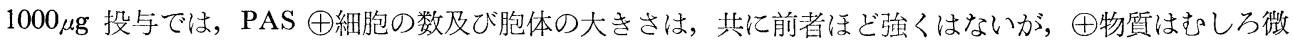
細顆粒状を呈し，核周よりも胞体周辺部に多く，空胞を有する去勢細胞は減少し，卵円形の $\mathrm{BZ}$ を多く認め た. また PMG あ $\mathrm{SH}$ 染色も共に○であつた，AZ には著変はないが， HZ は稍々その数を増加してい た．毛細血管は，充血像が軽度となり，管腔も ED の場合と同様に狭小を示していた.

(2) 重量変化: EO 投与量の増加に比例して，漸次下垂体重量も増量し，1000 $\mu \mathrm{g}$ 投与では対照群に較心 て48\%の増加率を示した.

(ii) 副腎重量 : 少量投与で一時著明に減少したが，投与量の増加につれて，下垂体と同様に次第に増加 し，やがて復元した。

(3) ET 投与群

(i) 下垂体に於ける変化

(1) 前葉の組織化学的所見: $0.04 \mu \mathrm{g}$ 投与では, 対照群に較べて著差はみられなかつた.

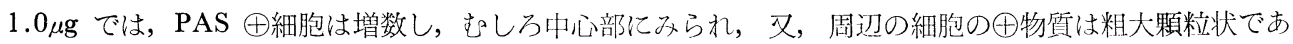
つた. 空胞を有する去勢細胞も多数にみられ核周に明調性を示していた.

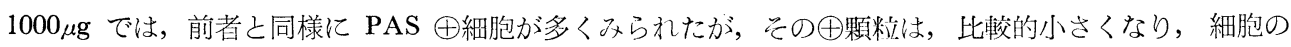
周辺に多く分布していた，空胞を有する去勢細肘むみられたが，ての核は肥大していた．PMG ではのであ つた.

(2) 重量変化：投与量の増大に伴い，重量の増加傾问を示し，1000 $\mu \mathrm{g}$ 投与では対照に比し $10 \%$ の増大率 を示した.

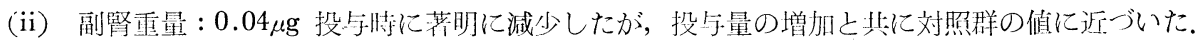

3. 合成エストロゲン投与群

(1) EED 投与群

(i) 下重体における变化

(1) 前葉の組織化学的変化 : 2.0i.u. 投与群では, PAS †細胞の数が少なかつた他は対照群に比し著差は

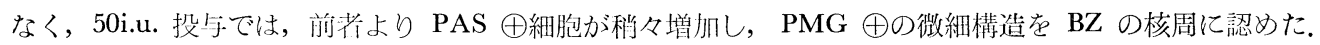
50000i.u. 投与では，PAS 丹顆粒は，比較的微細状となるか，依然として血管に富み細胞間隚は広いのが知 られた。

(2) 重量変化：表 5 及び図 3 の如く，50i.u. では減少するが，50000i.u. では，対照群と較べ 38\%の増加 率を示した。

(ii) 副篎重量 : 表 6 の様に，投与量に比例して増大するのが知られた.

表 5 各種各濃度エストロゲン投与による去勢ラットの下垂体重量 $(\mathrm{mg})$ の変化

\begin{tabular}{c|c|c|c|c|c}
\hline \multirow{2}{*}{$\begin{array}{c}\text { 投与エトトゲン量 } \\
\text { i.u./日 }\end{array}$} & \multicolumn{5}{|c}{ エストロゲンの種類 } \\
\cline { 2 - 6 } & ED & EED & Hex & Vall & TACE \\
\hline \hline 2 & $8.50 \pm 0.50$ & $7.50 \pm 0.48$ & $9.00 \pm 0.62$ & $9.25 \pm 0.25$ & $8.25 \pm 0.25$ \\
50 & $8.50 \pm 0.79$ & $6.00 \pm 0.42$ & $9.10 \pm 0.84$ & $9.50 \pm 0.85$ & $9.00 \pm 0.73$ \\
50000 & $9.50 \pm 0.29$ & $10.00 \pm 1.05$ & $10.00 \pm 0.97$ & $10.00 \pm 0.60$ & $9.20 \pm 0.75$ \\
\hline
\end{tabular}


図 3 各種各濃度エストロゲン投与による等ラットの下垂体重量 $(\mathrm{mg}) /$ 体重 $100 \mathrm{~g}$

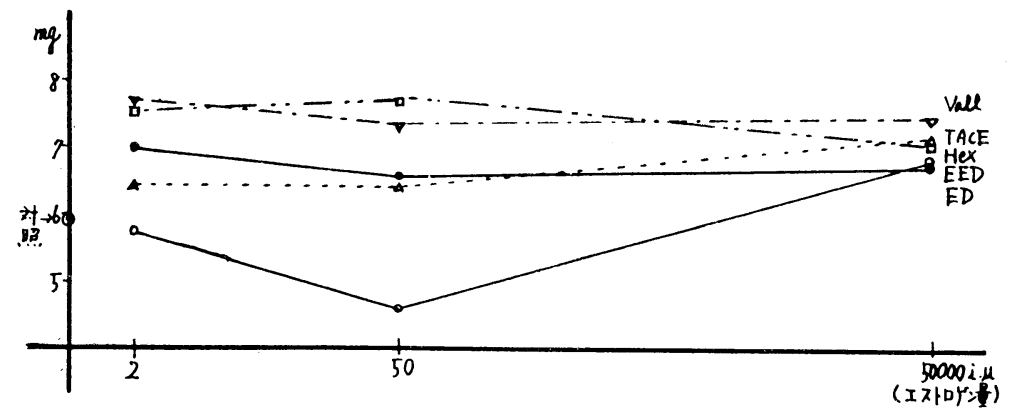

表 6 各種各濃度エストロゲン投与による勢ラットの副腎重量 $(\mathrm{mg})$ の変化

\begin{tabular}{c|c|c|c|c|c}
\hline \multirow{2}{*}{$\begin{array}{c}\text { 投与エストロゲン量 } \\
\text { i.u./日 }\end{array}$} & \multicolumn{5}{|c}{ エストロゲンの種類 } \\
\cline { 2 - 6 } & ED & EED & Hex & Vall & TACE \\
\hline \hline 2 & $40.00 \pm 0.60$ & $19.50 \pm 0.50$ & $26.00 \pm 1.05$ & $26.20 \pm 1.80$ & $22.00 \pm 3.60$ \\
50 & $31.00 \pm 3.00$ & $21.50 \pm 1.38$ & $28.50 \pm 1.26$ & $27.50 \pm 1.85$ & $22.05 \pm 1.43$ \\
50000 & $39.50 \pm 6.50$ & $29.05 \pm 3.10$ & $31.05 \pm 1.50$ & $30.00 \pm 2.00$ & $26.00 \pm 1.90$ \\
\hline
\end{tabular}

(2) Hex 投与群

(i) 下垂体に於ける変化

(1) 組織化学的所見: PAS では, EED の場命と同様て 20i.u. 投与では著变がみられなかつたが，50i.u. 投与では，丹顆粒は稍々微細となり，空胞を有し，又，BZ の数は減少し，50000i.u. 投与では，上述の傾 向が更に弦められたが毛細血管腔は広い特徵があつた。

(2) 重量変化: 投与量の増加にもかかわらず，著兴はみられなかつた.

(ii） 副腎重量：投与量が増すと増加の傾向がみられた.

(3) Vall 投与群

(i) 下垂体における変化

(1) 組織化学的所見：2.0i.u. 投与では著変なく，50i.u. でもほぼ同様であつたが，PAS 丹顆䊀は稍々微 細となり，50000i.u. 投与でも著変を示さず，PAS 丹細胞はその数を減じていた.

(2) 重量変化: Hex と同様に，投与量が変化しても著差はみられなかつた.

(ii) 副腎重量 : 投与量に伴つて, 増加の傾向を示した.

(4) TACE 投与群

(i) 下垂体に於ける变化

(1) 組織化学的所見：2.0i.u. 投的では著变をみなかつたが，50及び50000i.u. 投与では，PAS (顆䊉の 緻密之なるのが認りられた。

(2) 車量变化：投与量の増㧈に上り，平行的に下車体車量增加の傾向亘示し，50000i.u. 投尔では，対照 群に比し27\%の増加率を示した.

(ii) 副腎車量：投与によつて重量は增玑したが，推訃学的には有意の差はみられなかつた。

\section{第 2 項 正常群}

1. 対照（エストロゲンの溶媒のみを与えた群）：この群では，PAS 丹細胞は周辺に多くみられ，卵刉形

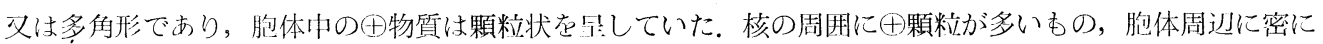


分布しているものなど各細胞でその分布は栐々であるが，前集の中心にあるせ細胞は，多角形で赤咮が搔く 顆粒は微細である印象在うけた，HE では，AZ, HZ 共に静止期のそれに比して差異を認めなかつた。また

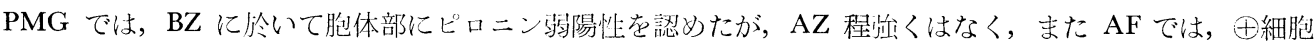

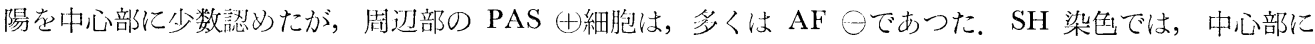
弱性:星した。

2. 天然エストロゲン投与群

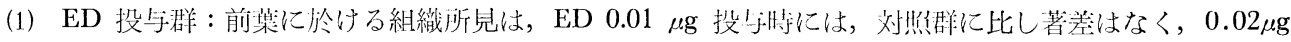
投与では，PAS 丹細胞の数及び陽性度は增し，顆粒は粗大となり，又，卵川形父は多角形を呈し，血管壁 に接してみられ，しかも周辽部に多くみら机た，血管は稍々充血像を呈し，細胞間隙は密であつた。AZ 及

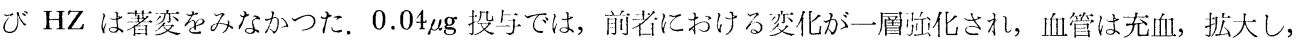
前葉周辺に PAS ↔細胞が多くみられ，その顆粘は粗大で，一部の細胞の核周には空胞の如く明るく染りら

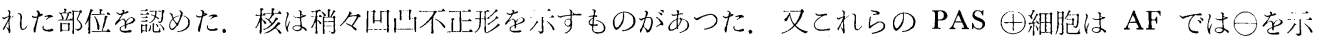
し，少数の中心部に散在する多角形の細胞は $\mathrm{AF} \oplus$ を呈した。 PMG では, 核周にピロニン好性の微細構 造がぬられたが，AZ 及び $\mathrm{HZ}$ では著変がなかつた。 Al-ph では，前葉周辺部に茶褐色の陽性部が認めら れ，又，SH 染色でも周辺に黒褐色の陽性部がみられたが，染色度は弱かつた（写真 $8 ， 17 ， 18 ， 22$ )。0.1

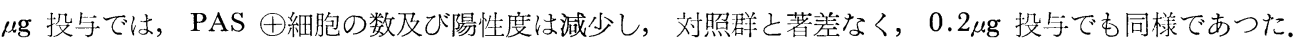

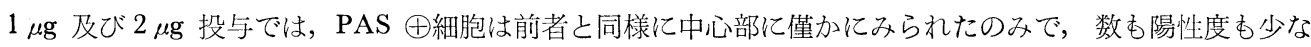
く，周辺部には甲細胞を認めなかつた，細胞間隙は稍々広いが，毛細血管の充血像はみられず，PMG です

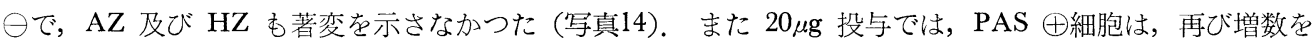
示し，中心部に散在性にみられ，形は多角形を示すすのが多く，染色度も弱く，その顆粒は非常に微細であ

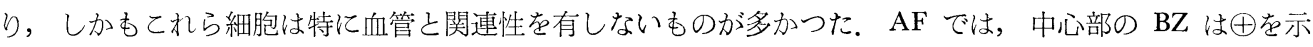

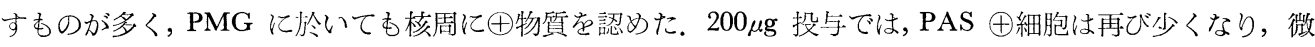
細状を呈し，血管も再び充血像を示すすのが多い，PMGは币であり，SH 染色では，中心部に弱陽性がみ

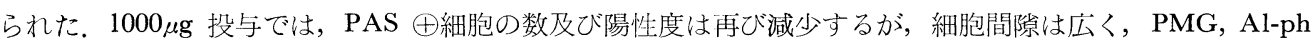
及び $\mathrm{SH}$ 染色に於いては，いづれも対照群之著差を見出しえなかつた（写真15，19，23）。

下垂体重量は，表 7 及び図 4 の如く, 対照に比して少量投与では著増し, 体重 $100 \mathrm{~g}$ 当り $0.04 \mu \mathrm{g}$ 投与時で

表 7 各種各濃度エストロゲン投与による正常ラットの下垂体重量 $(\mathrm{mg})$ の変化

\begin{tabular}{c|r|r|r}
\hline \multirow{2}{*}{$\begin{array}{c}\text { 投与エトロゲン量 } \\
\mu \mathrm{g} / \text { 日 }\end{array}$} & \multicolumn{3}{|c}{ エストロゲンの種類 } \\
\cline { 2 - 4 } & \multicolumn{1}{|c}{$\mathrm{ED}$} & $\mathrm{EO}$ & $\mathrm{FT}$ \\
\hline $0 \quad$ 対照) & & $6.30 \pm 0.33$ & \\
\hline 0.01 & $8.75 \pm 0.75$ & & \\
0.02 & $12.00 \pm 1.73$ & & \\
0.04 & $11.20 \pm 0.44$ & $8.00 \pm 2.04$ & $6.00 \pm 0.58$ \\
0.1 & $11.10 \pm 1.01$ & & \\
0.2 & $8.50 \pm 0.22$ & & $7.12 \pm 1.16$ \\
0.4 & $8.45 \pm 0.41$ & & \\
1 & $8.25 \pm 0.46$ & $8.50 \pm 0.91$ & \\
2 & $9.75 \pm 0.75$ & & $8.87 \pm 2.19$ \\
20 & $8.20 \pm 0.20$ & & \\
200 & $13.00 \pm 0.58$ & & \\
1000 & $10.66 \pm 0.33$ & $10.00 \pm 1.15$ & \\
\hline
\end{tabular}

第 36 巻 第 10 号 
図4 各種各濃度エストロゲン投与による正常ラットの下垂体重量 $(\mathrm{mg}) /$ 体重 $100 \mathrm{~g}$

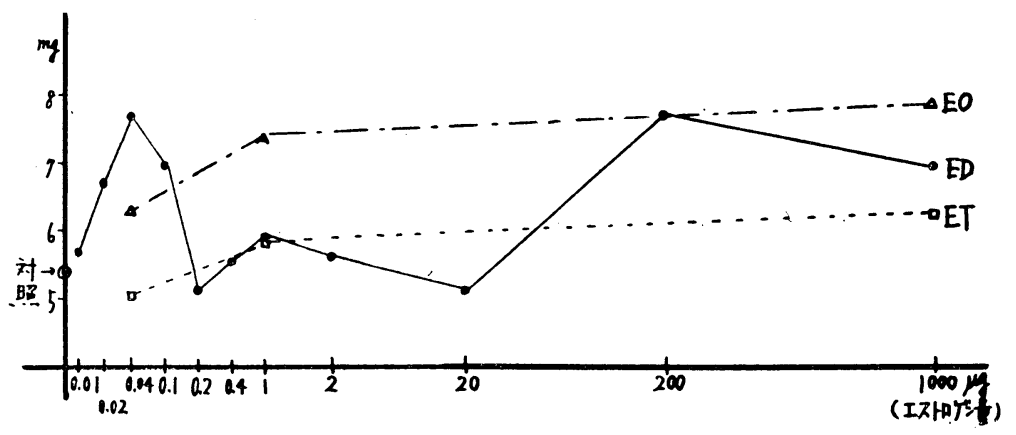

は7.6mgを示すが，中等量 $(0.2 \sim 20 \mu \mathrm{g})$ では再び減少して刘照と著差はなくなり，200〜1000 $\mu \mathrm{g}$ の大量投 与では再び增加し，刘照群に比して，30〜40\%の增大率を示した。

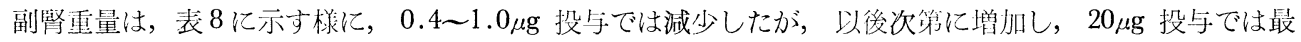

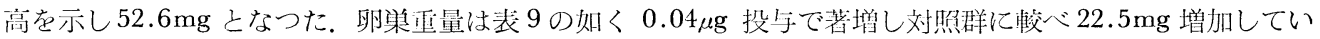
るが，中等量投与では，刘晒群のそれより減少し，更に $20 \mu \mathrm{g}$ 投与で一時的に増加しているが，200〜1000 $\mu \mathrm{g}$ 投与では再び刘照群のそれより減少しているのがみられた.

(2) EO 投与群

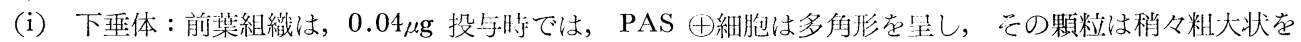

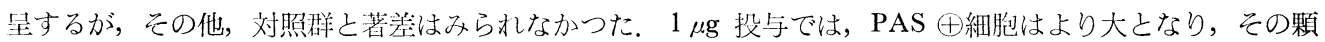
粒は粗大を呈し，空胞を有するものがみられ，核小体はEDのそれに較べ膨大していた，毛細血管の立血 は著明ではない（点真 9 )。1 $1000 \mu \mathrm{g}$ 投与では，PAS 陽性度は前老よりも弱く，細胞数の減少を示していた 他は，依然として前者と同様な变化を示していた。SH 染色では，周辺に黒䶂色の陽性部がみられた。重量 の変化は，その投与与量に伴い平行的に增大し，1000 $\mathrm{g}$ 投与では対照群に比して $45 \%$ の增加率を示した.

(ii）副婜重量 : 下重体に於けると同栐に増加し，1000 $\mu \mathrm{g}$ 投与では対照群よりも34\%の増加を示した.

表 8 各種各濃度エストロゲン投与によっ正常ラットの副腎重星( $\mathrm{mg}$ )の変化

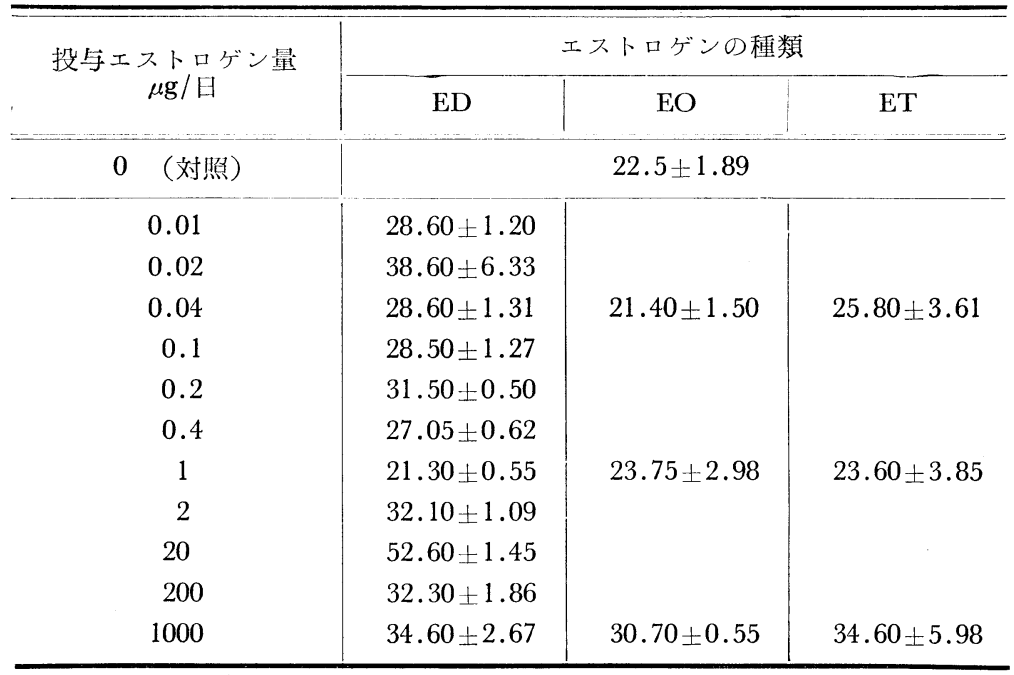


表 9 各種各濃度エストロゲン投与による正常ラットの卵巣重量 $(\mathrm{mg})$ の変化

\begin{tabular}{c|c|c|c}
\hline $\begin{array}{c}\text { 投与エトロゲン量 } \\
\mu \mathrm{g} / \text { 日 }\end{array}$ & $\mathrm{ED}$ & $\mathrm{EO}$ & $\mathrm{ET}$ \\
\hline $0 \quad$ (刘照) & \multicolumn{3}{|c}{ エストロゲンの種類 } \\
\hline 0.01 & $58.00 \pm 12.05$ & $41.00 \pm 3.73$ \\
0.02 & $62.70 \pm 8.65$ & & \\
0.04 & $63.50 \pm 4.64$ & $34.70 \pm 3.60$ & $37.25 \pm 3.25$ \\
0.1 & $50.30 \pm 3.62$ & & \\
0.2 & $44.10 \pm 1.45$ & & \\
0.4 & $39.20 \pm 2.50$ & & \\
1 & $30.70 \pm 3.64$ & $36.80 \pm 3.20$ & $37.60 \pm 2.68$ \\
2 & $29.60 \pm 2.73$ & & \\
20 & $42.50 \pm 9.82$ & & \\
200 & $30.90 \pm 6.63$ & & \\
1000 & $30.60 \pm 4.34$ & $52.20 \pm 2.55$ & $46.00 \pm 0.72$ \\
\hline
\end{tabular}

(iii) 卵巣重量 : 漸増して $1000 \mu \mathrm{g}$ 投与では，対照群のそれに比して $27 \%$ 増加を示し,この投与量では， $\mathrm{ED}$ 投与の際よりもむしろ増大していた.

(3) ET 投与群

（i）下垂体 : 0.04 $\mu \mathrm{g}$ 投与時，前葉組織は，PAS 及びその他の染色法によつて屯対照群と較べ著差はな かつた. $1 \mu \mathrm{g}$ 投与では, 前葉の周辺よりあ中心部において PAS $\oplus$ 細胞が多く, 顆粒は比較的緻密であり, 陽性度は弱いが胞体内に一様に分布していた，細胞は多角形のものもあるが，中心部では棈円形を呈し，空 胞を有するあのあある，核は一様に膨大し，クロマチン網が紋様となつているのがみられ，核小体は偏心位 をとり，核膜は肥厚していた， PMG では BZ に陽性の微細構造がみられ，また PAS 細胞は，AFで

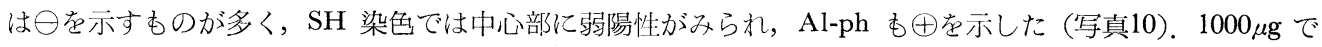
は PAS †細胞の数は，前者に較へ減少しているに反し，胞体の大きさは，前者よりもむしろ増大し，殊に 核が非常に大となり前者に於ける变化が一首迹く現われている感がある。核小体も膨大し平板状を呈してい

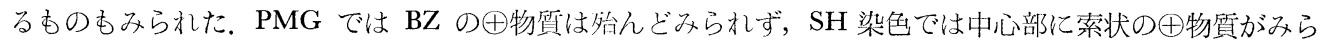
れ，Al-ph は前者に比し陽性度が減少していた。

下重体重量は，1 $1 \mu \mathrm{g}$ 投与ですでに増加していたが，1000 $\mu \mathrm{g}$ 投与では対照群に比し $2.5 \mathrm{mg}$ の増大を示し ていた.

（ii）副腎重量は，1 $1 \mu \mathrm{g}$ 投与では著変がないが，1000 $\mu \mathrm{g}$ 投与では，対照群に比し $12 \mathrm{mg}$ の増加を示して いた.

(iii) 卵单重量は，1 $1 \mu \mathrm{g}$ 投与では推計学的に有意の差がみられないが，1000 $\mu \mathrm{g}$ 投与では，対照群に比し $5 \mathrm{mg}$ の増加を示した.

3. 合成エストロゲン投与群

(1) EED 投与群

（i）下垂体 : 2.0i.u. 投与時には, 前葉に於いて PAS $\oplus$ 細胞は, 卵円形又は多角形を呈し, 血管に接して 位置し，丹物質は稍々粗大顆粒状であるが，同単位の ED 投与のそれに較べると微細であつた， PMG は ○であり，SH 染色では中心部に弱陽性:の褐色部位を認めた。 AZ 及び HZ に著変はなかつた (写真11).

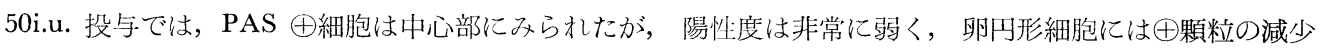
を認め，顆粒は微細状であつた。 PMG では核周囲にやの網様構造を認め，血管は稍々充血像を呈してい 


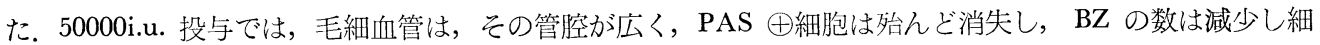
胞間隙は前二者に較べると広く，又 PMG は $\ominus$ となり， SH 染色で法陽性部は認めず，AZ の増加がみら れた。

下垂体の重量は，表10及び図 5 の如く，投与量により有意の差を示さなかつた，

(ii) 副腎重量: 表11の様に，50000i.u. 投与時に増大し，刘照に比し $17 \mathrm{mg}$ の増大であつた.

（iii） 卵栄重量 : 表12の如く，50i.u. 投与時は，対照群のそれに較べ著差を認めなかつたが，50000i.u. 投 与時注, 刘照群に比し $10 \mathrm{mg}$ 減少した。

表10 各種各濃度エストロゲン投与による正常ラットの下垂体重量 $(\mathrm{mg})$ の変化

\begin{tabular}{c|r|c|c|c|c}
\hline \multirow{2}{*}{$\begin{array}{c}\text { 投与エストロゲン量 } \\
\text { i.u./日 }\end{array}$} & \multicolumn{5}{|c}{ エストーゲンの 種 類 } \\
\cline { 2 - 6 } & \multicolumn{1}{|c|}{ ED } & EED & Hex & Vall & TACE \\
\hline 2 & $11.20 \pm 0.44$ & $7.12 \pm 0.17$ & $6.33 \pm 0.11$ & $6.25 \pm 0.46$ & $7.00 \pm 0.76$ \\
50 & $8.25 \pm 0.46$ & $6.25 \pm 0.79$ & $7.00 \pm 1.00$ & $6.25 \pm 0.44$ & $8.20 \pm 1.42$ \\
50000 & $10.66 \pm 0.33$ & $7.00 \pm 1.00$ & $9.00 \pm 1.50$ & $7.62 \pm 0.86$ & $10.25 \pm 0.69$ \\
\hline
\end{tabular}

図 5 各種各摆度エストロゲン投与による正常ラットの下垂体重量 $(\mathrm{mg}) /$ 体重 $100 \mathrm{~g}$

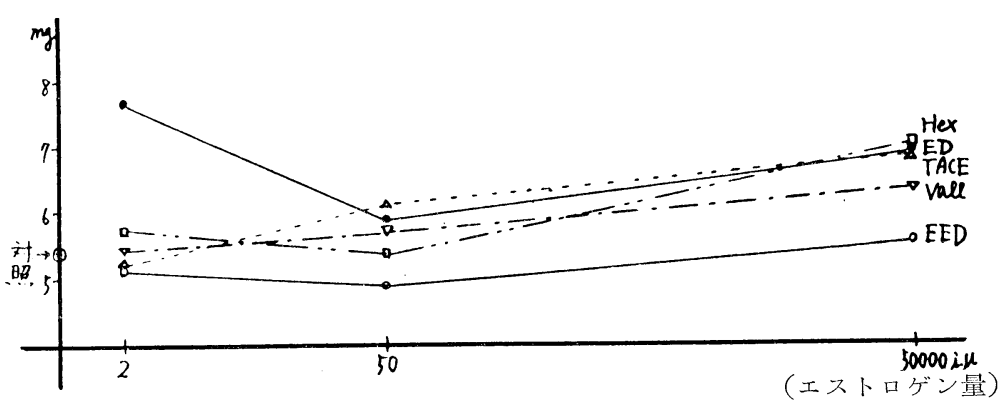

表11 各種各漕度エストロゲン投与による正常ラットの副腎重量 $(\mathrm{mg})$ の変化

\begin{tabular}{c|c|c|c|c|c}
\hline \hline \multirow{2}{*}{$\begin{array}{c}\text { 投与エトロゲン量 } \\
\text { i.u./日 }\end{array}$} & \multicolumn{5}{|c}{ エ ストロ ゲンの 種 類 } \\
\cline { 2 - 6 } & ED & EED & Hex & Vall & TACE \\
\hline \hline 2 & $28.60 \pm 1.31$ & $24.60 \pm 3.47$ & $20.00 \pm 1.19$ & $21.70 \pm 1.32$ & $21.80 \pm 1.34$ \\
50 & $21.30 \pm 0.55$ & $25.70 \pm 1.20$ & $28.00 \pm 4.72$ & $26.30 \pm 2.97$ & $28.80 \pm 3.66$ \\
50000 & $34.60 \pm 2.67$ & $39.60 \pm 8.38$ & $34.20 \pm 4.70$ & $30.50 \pm 1.84$ & $29.50 \pm 1.26$ \\
\hline
\end{tabular}

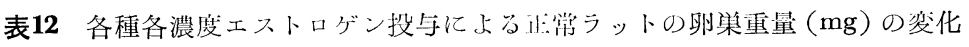

\begin{tabular}{c|c|c|c|c|c}
\hline \multirow{2}{*}{$\begin{array}{c}\text { 投与エストロゲン量 } \\
\text { i. } \mu \text {. }\end{array}$} & \multicolumn{5}{|c}{ エ ストロ ゲンの 種 類 } \\
\cline { 2 - 6 } & ED & EED & Hex & Vall & TACE \\
\hline \hline 2 & $63.50 \pm 4.65$ & $32.40 \pm 1.95$ & $37.00 \pm 6.25$ & $34.70 \pm 5.31$ & $50.80 \pm 13.12$ \\
50 & $30.70 \pm 3.64$ & $42.70 \pm 2.70$ & $38.60 \pm 4.70$ & $36.70 \pm 6.86$ & $43.50 \pm 3.05$ \\
50000 & $30.60 \pm 4.34$ & $31.00 \pm 3.00$ & $4.00 \pm 12.90$ & $45.70 \pm 4.72$ & $44.00 \pm 3.97$ \\
\hline
\end{tabular}


(2) Hex 投与群

（i）下垂体：2.0i.u. 投与時の前葉細胞は，中葉に接して稍々粗大な PAS $\oplus$ 細胞を認めこれらは卵帅

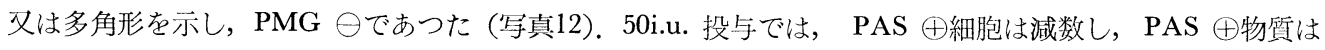
微細顆粒状を呈し，特に卵円形細胞には脱顆粒像を認め，広い管腔を有する血管に富んでいる特徴があつた。 50000i.u. 投与では，PAS 細胞は，前者と同様中心部にみられたが，その数は少く形は多角形を呈し， PMG $\oplus の \mathrm{BZ}$ むあつた. 下垂体重量は，投与量の増加に伴つて漸增したが，50000i.u. 投与では対照群に比 して4.3mgの増加であつた.

(ii) 副腎重量 : 前者と同様に，投与量に平行して増大を示した.

(iii) 卵巣重量 : 投与量の増加により有意の差を示さなかつた.

(3) Vall 投与群

（i）下垂体：前葉組織は，2.0i.u. 投与時では，対照群に比し著差を認めなかつた．50i.u．投与で，PAS

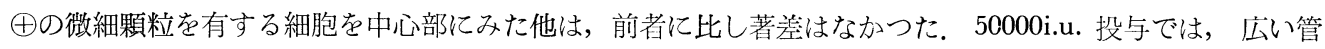
腔を有する毛細血管に富み，PAS 細胞は減数していた他は，前二者に較心゙著差はなかつた。 下垂体重量 は，投与量に比例して僅かに肥大するのが知られた。

(ii) 副腎重量 : 50i.u. 及び 50000i.u. 投与時に於いて, 対照に比し32〜 55\%の増量を示した.

(iii) 卵巣重量 : 投与量の变化に伴い増量し，50000i.u. 投与時に対照群に比し $4.7 \mathrm{mg}$ の増大を示した.

(4) TACE 投与群

（i）下重体 : 2.0i.u. 投与時の前葉は，稍々微細な PAS $\oplus$ 顆粒を有する卵円形又は多角形の細胞を認め

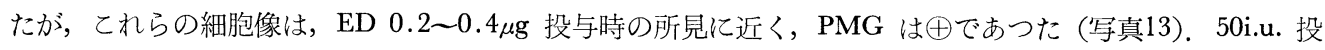

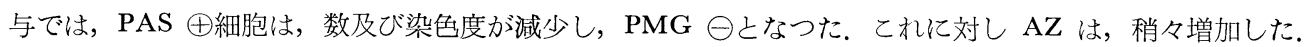
50000i.u. 投与では，中心部に血管とは位置的関係のない，微細顆粒を有する PAS (細胞を認め，AF $\oplus$

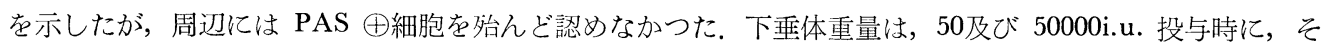
れぞれ対照群より 2 〜 mgの増大を示した.

(ii) 副腎重量 : 50及び 50000i.u. 投与時に，それぞれ対照群より6.3〜 7 mgの增大を示した.

(iii) 卵策重量 : 投与量が変化しても, 推計学的に著空を示さなかつた。

\section{第 3 項 小括}

以上により，去勢動物に少量の $\mathrm{ED}$ を投与すれば，下垂体の組織像及び重量には変化をみないか，投与

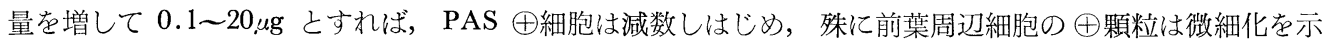
し，去勢細胞中の空胞にあ縮小がみられる様になつた，乙のさい ED 投与に応ずる細胞は PAS $\oplus ， \mathrm{AF} \ominus$ の周辺細胞が多かつた，又，投与量が極めて大量となると，丹細胞の粗大顆粒は殆んど消失し，微細顆粒状 を呈する様になつた， AZ は，ED の投与量の増加により，一般に増数したが， HZ は著差を示さなかつ た．又，正常群に於いては，ED の極めて微量投与では，著变がみられなかつたが，少量投与では，PAS $\oplus$ 物質は粗大となり，周辺の血管の近傍に多く現われ，PMG は円を示した. 更に投与量を増加すると，周辺

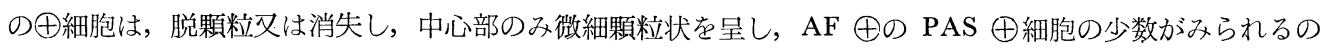
みとなつた. 又 $\mathrm{EO}$ 投与では，乙れらの変化が $\mathrm{ED}$ 程著明には起らず，その $1000 \mu \mathrm{g}$ 投与時の前葉所見 は，ED20〜 200 $\mu \mathrm{g}$ 投与時のそれに近い像を示したが，更にETに至つては，その変化は弱く，乙れに関して は後述する. 又合成エストロゲンとこれら天然エストロゲン投与の所見を比較すれば，表13，表14の如くで ある。

下垂体重量の変化は, エストロゲン各製剤により, 多種な変化を示したが，去勢群では，その大量を投与 すれば増大して一定の值に近づく傾向がみられた，又副腎に関しては，去勢群も正常群も共にエストロゲン 投与により増加の傾向を示したが，その標準誤差を考慮すれば断定は出来ない. 卵巣重量は，エストロゲン 製剂により下垂体に於けると同様に様々な変化を示し，それが卵巣，子宮及び腟粘膜に及ばす効力に差があ る事を示した。 
表13 各種各濃度エストロゲン投与による去勢ラットの下垂体前葉の組織化学的変化

\begin{tabular}{|c|c|c|c|c|c|c|c|c|c|}
\hline \multirow{2}{*}{ 染色法 } & \multirow{2}{*}{\multicolumn{2}{|c|}{ 投与量 i.u./日 }} & \multicolumn{7}{|c|}{ エストロゲンの種類 } \\
\hline & & & $\mathrm{ED}$ & $\mathrm{EO}$ & ET & EED & Hex & Vall & TACE \\
\hline \multirow{4}{*}{ PAS } & & (対照) & \multicolumn{7}{|c|}{ H } \\
\hline & & 2 & $H$ & H & $H$ & + & $H$ & H & $H$ \\
\hline & & 50 & + & $H$ & $H$ & + & + & H & + \\
\hline & & 50000 & + & + & H & + & + & + & + \\
\hline \multirow{4}{*}{ PMG } & & （対照） & \multicolumn{7}{|c|}{+} \\
\hline & & 2 & + & + & \pm & + & + & \pm & + \\
\hline & & 50 & - & + & + & + & - & + & + \\
\hline & & 50000 & - & - & - & - & - & 一 & - \\
\hline
\end{tabular}
熊 (一) 陰性
（士）弱陽性
（十）中等度陽性
(H) 強陽性

表14 各㮔各濃度エストロゲン投与による正常ラットの下垂体前葉の組織化学的変化

\begin{tabular}{|c|c|c|c|c|c|c|c|c|c|}
\hline \multirow{2}{*}{ 染色法 } & \multirow{2}{*}{\multicolumn{2}{|c|}{ 投与量 i.u./日 }} & \multicolumn{7}{|c|}{ エストロゲンの種類 } \\
\hline & & & ED & $\mathrm{EO}$ & ET & EED & Hex & Vall & TACE \\
\hline \multirow{4}{*}{ PAS } & & （対照） & \multicolumn{7}{|c|}{+} \\
\hline & & 2 & $H$ & + & - & + & + & + & + \\
\hline & & 50 & - & $H$ & H & + & - & + & - \\
\hline & & 50000 & + & + & + & - & + & + & H \\
\hline \multirow{4}{*}{ PMG } & & （対照） & \multicolumn{7}{|c|}{ \pm} \\
\hline & & 2 & + & + & - & - & - & - & + \\
\hline & & 50 & - & - & + & + & - & \pm & - \\
\hline & & 50000 & - & \pm & \pm & - & + & - & \pm \\
\hline
\end{tabular}

第 4 章 考按並びに結論

性ステロイドホルモンが，性腺に作用する事は，周知のところで，古くから臨床面で応用されているが， 更に性中枢，殊に下垂体えも作用する事は，Hohlwegや Halpern ${ }^{38)}$ らにより研究報告されたところである. この際, Gの変化を解明するために, 個体又は並体動物の下垂体及び性腺㵴器の形態学的研究, 生体検定 ${ }^{39)}$ (6)

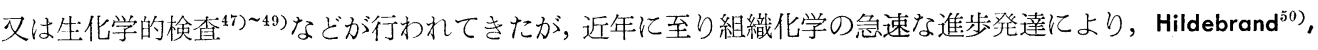
Rennels ${ }^{51)}$ らが報告した様に，物質代謝の面からも検討を加える事が出来る様になつた。

さて PAS 反応は，過沃度酸が 1，2 グリコール基に作用して 2 分子のアルデヒド基を生ずるいわゆる Cytol 反応 (Malaprade 反応 ${ }^{53}$ ) に基づくのであるが，巴物質としては, 多糖類, 粘液多糖類, 糖蛋白あるい は糖脂質などが考えられる。ラット下垂体において，唾液消化試験及び $1 \%$ T ジーはみられなかつた事，又50\%アセトン固定の組織片では PAS 巴物質が始んど消失した事及び同様に60 \%アルコール固定では陽性は消失したが，80\%アルコール固定では PAS 陽性度に著変のなかつた事などを

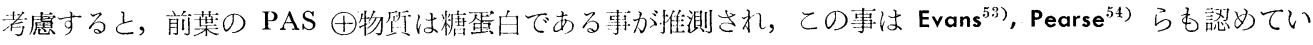
るが，他面 FSH を化学的に糖蛋白として $\mathrm{Li}^{555}$ は取り出している. 又 $\mathrm{LH}$ では Otuka ${ }^{56)}$ が, TSH は Fels 


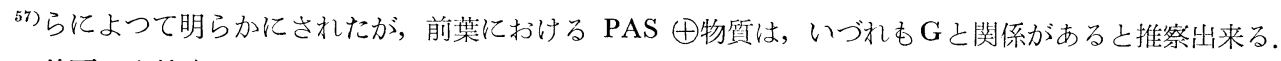

他面, 去勢時に, 前葉は多量のG 特に FSH を含むとなす多くの研究 $\left.{ }^{58) ~} 60\right)$ がみられるが，てのさい一般 に BZが増加し， $\mathrm{AZ}$ は一応減少するが， $\mathrm{HZ}$ については意見が一致していない61) 62)。しかしラットでは, いわゆる去勢細胞が出現し，乙れは粗大な PAS 丹顆粒を含む事から，乙の顆粒之BZ とは，機能的にも密 接な関係が存在するあのと推定される，更に性周期については，下垂体細胞成分に関して伊藤が示してい る様に，機能的に FSH 放出時と考えられる静止期の終りから，発情前期にかけて BZ の数が増加するが， 私もこの時期に PAS $\oplus$ 顆粒の出現が，僅かではあるが周期的に変化するのをみた。この事によつても $\mathrm{G}$ PAS $\oplus$ 顆粘の出現が無関係である之は云えないであろう.

1940年に Romeis は BZ に $\beta$ 細胞と $\delta$ 細胞の 2 種類がある事を提唱し，続いて Gomori は，AF により $\beta, \delta の 2$ 種類の細胞を識別したが，その後 Pearse，Wilsan ${ }^{84)}$ 及び Barrnett ${ }^{63)}$ らの変法が報告されて， $\beta ， \delta$ 細胞の区別は，より容易となつた。一方 Purves ${ }^{23) 64)}$ らは，いわりる塩基好性細胞を “Gonadotrophs”之 “Thyrotrophs”の2つに分け, Wilson は, PAS-red と PAS-purple と呼んでおり, Pearse ${ }^{65}$ は は “Mucoid” 細胞之呼称し，乙れを 8 型に分類している.

さて ED 投与時における前葉細胞, 殊に BZ は, 少量投与で PAS $\oplus$ 物質は, 前葉の中心部及び周辺, 特に血管周囲に著明に現われ，丹顆粒は粗大であり，また PMG によつて核の周囲及び胞体周辺にピロ二 ン好性の網㥞構造が出現した事は Caspersson ${ }^{66}$ 亿より，リボ核酸を多量に保有する細胞は，蛋白合成機能 及び增殖機能之密接な関係を有するといわれており，Pearse あ “Mucoid”細胞の産生時には，リボ核酸が 増量するととを述べている，更にこの時卵巣重量の増加がみられた事をあわせ考えると，前葉機能の直進を 思わせる。乙れらの点につき Salhanick $\left.{ }^{68}\right)$ らは去勢猿に少量の ED (1 日10 $\left.\mu \mathrm{g}\right)$ を長期間投与したが著変な $く, 1$ 日 $100 \mu \mathrm{g}$ 宛の長期投与で下垂体 $\mathrm{G}$ が $\ominus$ となり, 投与中止後 20 日して再び $\mathrm{G} の$ 産生をみた報告を肯定す るあのであり，すでそいわれている如く少量のエストロゲン投与は，Gの放出を来さしめるあのであ万う

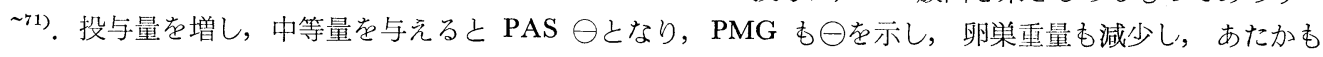
前葉機能は娍退したかの感がある，去勢ラットと異つて自己の生産するエストロゲンがある事から，ラット は正常状態を保つており, 投与エストログンを充分利用し, 前葉機能の充進を必要之しないのであろう。

去勢劷物においては，性腺機能は完全に停止して，下垂体 $\mathrm{G}$ 之性ステロイドとの相関関係から前葉機能は

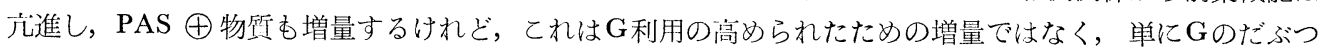
いた姿であり，ために顆粒は粗大である，てれにェストロゲンを投与すれば，乙の生理作用をうける藏器の 機能は光進するために, 投与エストロゲンの利用消費は, 直ちに前葉に反応し, $\mathrm{G}$ の分泌は高められる。乙

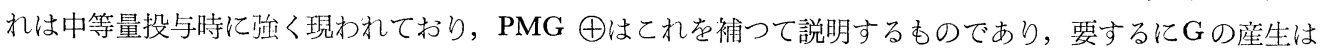
高められているけれどあ, 投与エストロゲンが大量となると，エストロゲンの飽和を来しいわゆる Feedback 現象加 G分泌を抑制し, PAS $\ominus$ 化を招来する。

体内で検出されるエストロゲンは, ED, EO, ET の3者から成つており, 血流により目的藏器に達して 作用を及ぼすと共に，体内代謝過程でこれら 3 者の移行が行われ，最終代謝産物として体外に排出されるの であるが，乙の動態を知るために，血中及び尿中エストロゲン分劃を追究したあのは極めて多い67)，中であ $\mathrm{EO} は$ は，ED より発情力の弱いエストロゲンとして臨床面であ屢々使用されたのであるが，ETについては 極めて関心が少なく，Frederick らは，子宮重量測定にさいし，特異な作用が考えられる事を推察し, Puck ${ }^{72}$ は，他のエストロゲン製剤と異り，子宮頸部内膜に作用を及ぼすと報告しているが，一般には ET は，最

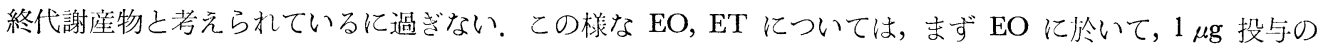

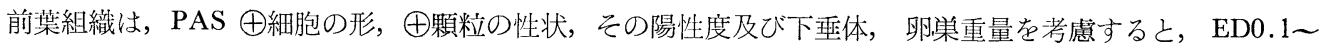
$0.4 \mu \mathrm{g}$ 投与時の所見に似ており，同様に $1000 \mu \mathrm{g}$ 投与時のそれいは，ED20 200 $\mu \mathrm{g}$ 投与時の所見に類似点を

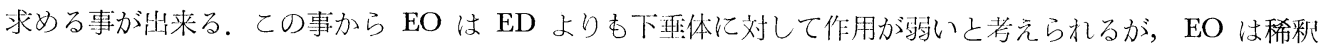
段階が少ないので，今後の検討を要する屯のがある，次ざに ET には，投与時に卵宩重量の変化は始んど みられなかつたのであるが，前葉組織殊に BZ の変化存誌めた。即ち大量投与で PAS 丹細胞核は肥大し， 
核周の凹山不正形，核小体の膨大及びクロマチン網の紋様化がみられたが，乙れは腫煬細胞の哦生過程にみ られる核に似ているが，Auerbach は機能の旺盛な細胞にこの様な所見がみられると述べており，又浜崎 ${ }^{33}$ も核の上述の様な変化は，その細胞機能が充進している事を示すと報告しているが，従来卶んどその発情作 用が弱いために注目されなかつた ET が，卵巣及び副䇾えは著明な変化を及ばさずに，前葉にのみこの様 な作用を有する事は，単にエストロゲン代謝産物に過ざないと考えるには，あまりにあ舆味ある点を残して いる。

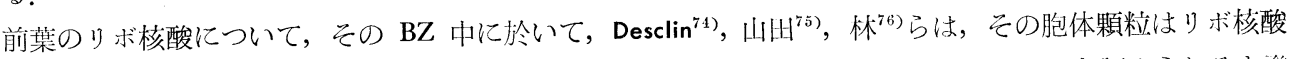
の性質をむつていないと述べいるが, Pearse，Wolfe ${ }^{77)}$ 及び Dempsy らは，BZ 亿おいてあ認められると発

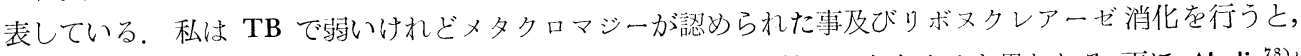
ピロニン好性の微細構造が消失した事は，BZ に於いてあ, リボ核酸は存在すると思われる.更に Abolin ${ }^{88}$ は 蛋白体の産生には，リボ核酸が必要であるが，糖蛋白の産生には不要であると述べているが，Pearse は反対 の意見を発表している。私の実験に於いては，蛋白代謝を追究するために，大原法により SH 基の変化をみ たが，有意の差を認めえなかつたのは，Abolin のいう如く，蛋白代謝に関係のないためであるか，又は染 色方法の都合上，切片を $9 \mu$ 以下にはつくれなかつたため 細胞の区別が出来なかつた理山によるのであるか は，䨤に今後の検討を要する。

天然ホルモンは，注射によつて効果を示すが，内服では著しく効果をおとすとされ，乙机は，肝臓酥素系 によるエストロゲン不活性化によると考えられている。合成エストロゲンは, 内服によつてあての様なとよ は少なく，今日では臨床面で広く用いられているが，合成エストロゲンあ不活性化されないわけではない，

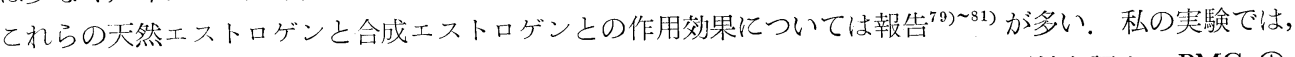
先づ EED 投与時の所見は，卵円形又は多角形の PAS 丹細胞内に，稍々粗大な顆粒を認め，PMG ( 血管の充血像及び PAS 陽性度などは，ED 投与時の 0.2 0.4 $\mu$ g 投与の所見に近く”, 50i.u. ではかなりの PAS $\oplus$ 顆粒の消失及び染色度がおちている事は, ED $1 \mu \mathrm{g}$ 投与像に近い. 又 Hex, TACE に於いて 2.0i.u.

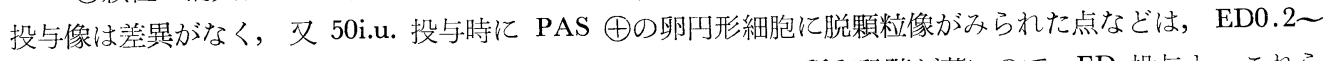
$0.4 \mu \mathrm{g}$ 投与時の所見に類似している。 これら合成エストロゲンの稀粎段階が荒いので，ED 投与と，乙れら 合成エストロゲン投与とにより，全く同じ所見はみられなかつたが，更に下垂体重量，卵巣重量及び去勢群 投与時の所見を考えあわせると，前葉に対し EED は ED と近似した作用を及ぼし，Hex，TACE はかな り弱い力しか有しない，この事は，各製剤の国際単位は同一であつても，性腺に対する効果と前葉に対する それは，必ずしも同一でないからであろう。更に Vall 投与では, 前葉の組織化学的像に著変なく, 下垂体 重量及び卵巣重量にも有意の変化を認めないが，大量投与に至つて始めて卵巣重量が増加したのは，他の工 ストロゲンと異り，発情作用は同じであつてあ下垂体，卵巣に対しては機質的変化を及ぼす事が極めて少な いと考光られる。

蛋白代謝之密接な関係を有する SH 基飞関して Ladman ${ }^{82) 83)}$ らは，BZ 亿於いては，FSH の消長に併行 して币物質の出現を認めているが, 私の場合は前葉周辺に陽性部を認めた場合ああつたが, その陽性度之特定 な細胞との関係を断定する事はむづかしいが，ED 少量投与時に，周辺部にのが強いのは PAS 及び PMG 所見と考えあわせると，蛋白代謝の克進を推察する事が出来，適当な染色法を用いるならば，SH 基の面か らも G産生の機序を更に明確にする事が出来るであろう.又 Al-ph に於いて Abolin あ述へている如く, BZ に於いては, 著変を認めない. 又 $\mathrm{AZ}$ は円物質を有しているが, エストロゲン投与量との間に一定の関係 は見出しえなかつた。

よつて私は，ラットを用いた実験の結果から要約して次の如く結論する。

（1）エストログンの連続投与を行えば，下垂体前葉機能は，その少量投与では刺㦸的に，大量投与では抑 制的に影響された。

（2）天然及び合成エストロゲン投与の下垂体前葉えの影響の強さを比較すれば， Estradiol EEthinylestradiol $>$ Hexron, Chlorotrianisene $>$ Estrone $>$ Vallestril の順に弱くなる. 
（3）ET は，前葉に対して弱いながらも刺㦸的に作用し，乙の点から ET を単なる代謝産物と考えるこ とに対し再検討の要がある。

（4）エストロゲン投与により下垂体前葉の塩基好性細胞に変化がみられ，乙れら 細胞中に含まれる PAS 陽性物啠は，下垂体前葉の機能亡一定の関係がある事が示された。

（稿点終っに臨み，終始御想篤な御指導と御校閲を賜りました恩師赤須教授に心から感㴬致します。）

\section{参 考 文 献}

1) Hohlweg, W. : Klin, Wschr. $11: 321,1932$

2) Meyer, R.K., et al. : Endocrinol. $16: 655,1932$

3) Zondek, B. : Nature. $154: 154,1944$

4) Brown, W.E., et al. : Am. J. Obst. a. Gynec. $65: 733$, 1953

5) Zondek, B. : Surg. Gynec, \& Obst. 88 : 783, 1949

6) Greep, R.O., a J.C. Jones.

: Recent. Prog. Hor. Res. 5 : 197, 1950

7) Holweg, W. : Klin. Wschr. $13: 92,1934$

Fevold, H.L., et al. : Am. J. Physiol. 114 : 508, 1936

1947

10) 五十嵐正雄 : 日産婦誌，8:1395，1956

9) Bradbury, J.T. : Endocrinol. $41: 501$, 1950

12) 佐藤 孝 : 日産婦誌, $8: 693,1956$

11) Sayers, G. : Physiol. Rev. $50: 241$,

14) 奥田久ら : 産婦の進歩, $6: 290,1954$

15) 成田久ら：産と婦，21:932，1954

16) 塚

原 栄: 日産婦誌, 4:965, 1952

17) Lothringer, S. : Arch, Mik. Anat. 28 : 257, 1886

Romeis, B. : Handbuch d. Mik. Anat. d. Menschen, Bd VI. Tl 3, Springer Berlin, 1940

19) Pearse,

A.G.E. : J. Path. a. Bact. $64: 811,1952 \quad$ 20) Herlant, M. : Bull. Acad. roy. Sci. Belg, $28: 588$, 1942 抄録 21$)$ Mc Manus, J.F.A. : Nature, Lond. $158: 202,1946 \quad 22)$ 井上和子ら : 日病会 誌, $38: 109,1949 \quad 23)$ Purves, H.D., a. W.E. Griesbach : Endocrinol. $49: 244,1951$

菊地 享: 十全会誌，57:102，1955 25）岡本耕造 : 顕微鏡的組織化学 医学書院, 東京, 1958 26) Pearse, A. G.E. : Histochem. Church. Lond. $1953 \quad$ 27) Gomori, G. : Mik. Histochemist., Univ. Chicago Press. Chicago, 1952

28) 大原実ら：医学と生物, $11: 344,1949$

29) Hill,

R.T. : J. Physiol. 83 : 129, 1934

30) Wolfe, J.M. et al. : Z. Zellforsch $17: 420,1933$

31)

松田正二：日産婦誌，11:547，1959

32) 佐藤五美: 日産婦誌, $11: 1513,1959$

33) 伊藤

美禰子：臨婦産, $7: 693,1953$

34) Catchpole, H.R. : J. Endoc. $6: 218,1949$

35) Rothermich

O., a. M. Foltz : Endocrinol. $27: 37,1940$

36) 小林 博 : 日産婦誌, $8: 621,1956$

37）赤

須文男 : 日産婦誌, $7: 655,1955$

38) Halpern, S.R. a F.E.D' Amor. : Am. J. Physiol. $115: 229$, 1936 39) Finerty, J. C., a. R.K. Meyer, : Endocrinol. $46: 494,1950$

40) 小栄次郎 : 日内

泌誌，16:89, 1940

41) 藤井久四郎：日婦会誌，35:95，1940

42）原田基男：日外会誌,

$56: 396,1955$

43) 林 幹夫 : 名古屋医学, $69: 65,1955$

44) Cutuly, E. a. E.C. Cutuly. :

Endocrinol. $22: 568,1938 \quad$ 45) Bidduliph, C. a. R.K. Meyer. : Proc. Soc. Exp, Biol. \&. Med. 63 : 92, 1946 46) 斎藤信彦 : 日産婦誌, $11: 1899,1959 \quad 47)$ Hilton, A.S., et al. : J. Clin. Endocrinol. $12: 310,1952 \quad 48)$ 土肥 定: 日産婦誌, $10: 1309,1958$

49) 住谷孝子：産婦

の進歩, $6: 71,1954$

50) Hildebrand, J.E., et al. : Z. Zellforsch. $46: 400,1957$

51) Rennels,

E.G. : ibid. $45: 464,1957$

52) Malaprade, M.L. : Bull. Soc. Clin. biol. Paris. $5: 833,1934$

53) Evans, H.M., et al. : Science. $89: 249,1939$

54) Pearse, A.G.E. : Nature, Lond. 162 : 651, 1948

55) Li, C.H., et al. : Science. $109: 445,1949$

56) Otuka, H. a. Y. Nada. : J. Biochem. Japan 41

:547, $1954 \quad$ 57) Fels, I.G. et al. : Endocrinol. 51:349, 1952

: 24, 1936

1769,1959

誌, $31: 82,1956$
59）滝上 進：日産婦誌，9:1402，1957

61) Gumbreck, I.G. : Am. J. Anat. $101: 321,1957$

63) Barrnett, R.J. : Endocrinol. 59 : 398, 1956
58) Allright, F. : ibid. 20

60) 助川繙夫 : 日産婦誌, 11 :

62) 山田和麻呂ら : 解剖

64) Purves, H. D. a. W.E. 
Griesbach. : ibid. $55: 785,1954$

65) Pearse, A.G.E. : J. Path. \&. Bact. 64 : 791, 1952

67) Hisaw, F.L. et al. : J. Clin. Endoc. $14: 1134,1954$
69) Moore, C.R. et al. : Am.

68) Salhanick, H.A., et al. : J. Clin. Endoc. a Metab. 12 : 310, 1952

70) Lane, C.E. a. F.L. Hisaw. : Anat. Rec. 60 : Suppl, 52, 1934

J. Anat. $50: 13,1932$

72) Puck, A. a. K.A. Hüber. : Acta. Endocrinol. 22 : 191,

Frank, R.T. : J.A.M.A. $114: 1504,1940$

74) Desclin, L. : Endoc-

1956

73）浜崎幸雄 : 紐胞核の生理と病理，永井書店，大阪，1954

1959

76) 林

幹夫 : 名古屋医学, $69: 52,1955$

77) Wolfe, J.M. : Am. J. Anat. 85 : 309, 1949

78)

Abolin, L. : Exp. Cell. Res. 3 : 1, 1952

79) 中山徹也：日産婦誌，8：1337，1956

80）赤須

文男ら：日産婦誌， $3: 335 ， 1951$

81) 小林隆ら：産と婦， $23: 360,1956$

82) Ladman,

A.J. a. R.J. Barrnett. : Endocrinol. 54 : 335, 1954

83) Barrnett, R.J. : ibid. 55 : 484, 1954

84)

Wilson, W.D. a. C. Ezrin。: Am. J. Path. $30: 891,1954$ 


$$
\text { 木 村 論 文 附 図（その 1) }
$$

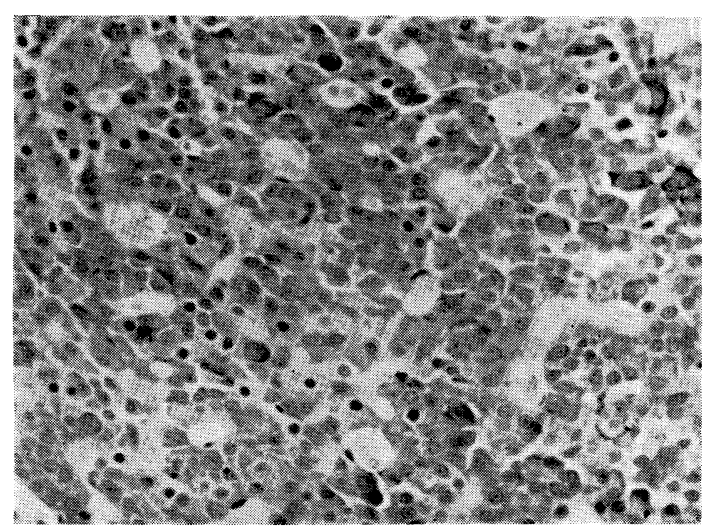

写真 1 静止期 $($ PAS $\times 350)$

血管周囲住卵円形のPAS $\oplus$ 細胞あり

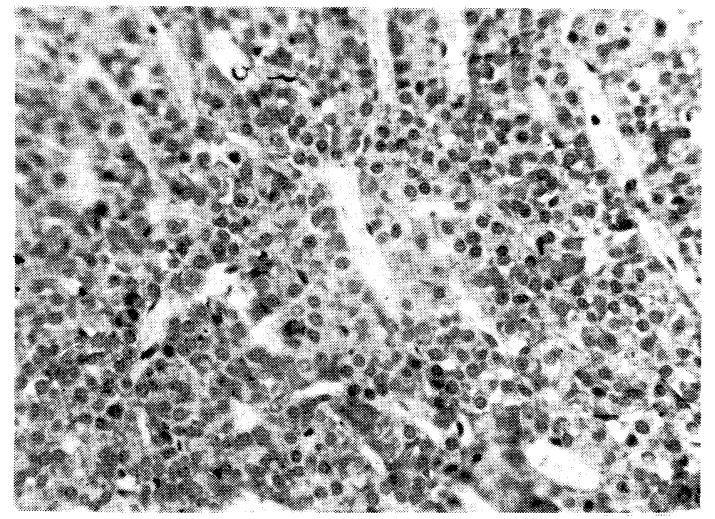
写真 2 発情後期 $($ PAS $\times 350)$

$\mathrm{PAS} \oplus$ 細胞の顆粒は微細となる

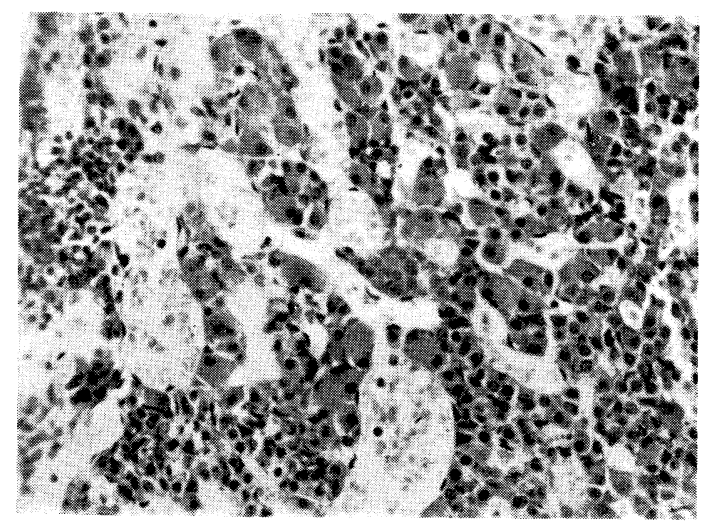

写真 4 去勢後60日（PAS $\times 350 ）$

血管腔は広く PAS (紐胞は数を增している

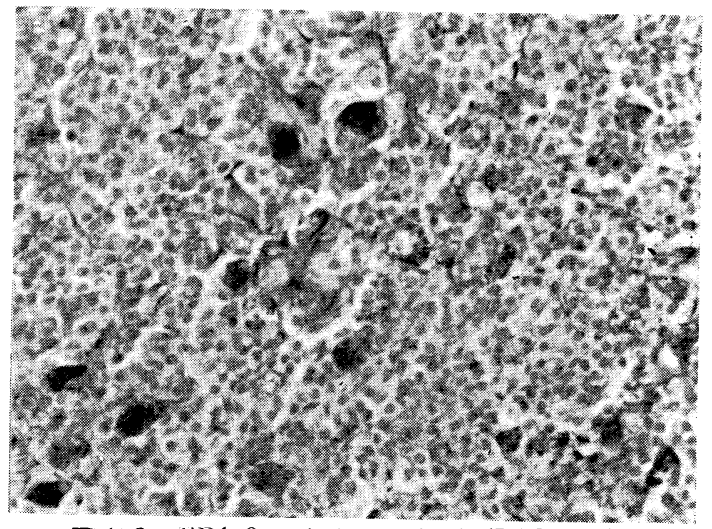

写真 $6 \mathrm{ED} 1.0 \mu \mathrm{g}$ 投与 : 走泶群 $(\mathrm{PAS} \times 350)$ PAS $\oplus$ 顆粒は稍微紼化を示す

去勢後 30 日の像に近く $\mathrm{PAS} \oplus$ 紐胞の顆粒も粗大状芭 呈守 


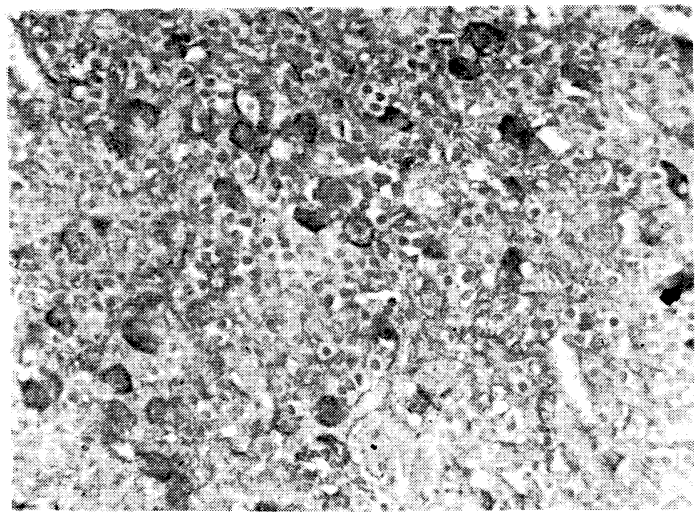

写真 7 ED. $1000 \mu \mathrm{g}$ 投与: 去勢群 $(\mathrm{PAS} \times 350)$ 去勢細胞の数は減少し, その環状空胞は殆んご消失し ている。

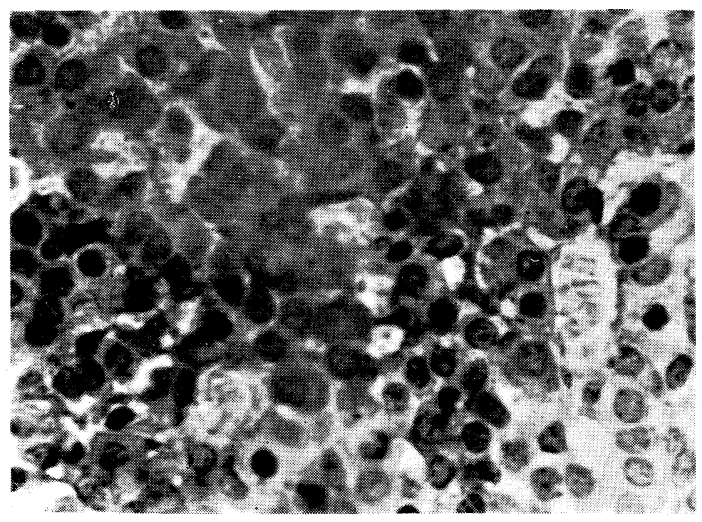

写真 $9 \mathrm{ED} 1 \mu \mathrm{g}$ 投与 $(\mathrm{PAS} \times 930)$

幸じて $\mathrm{ED} 0.01 \mu \mathrm{g}$ 投与像に近似している

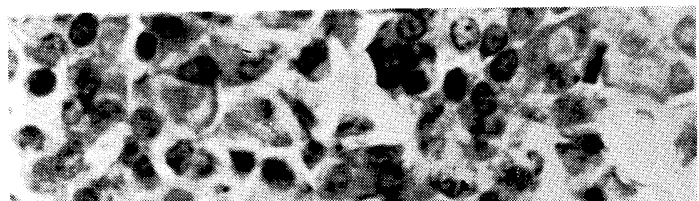
$+23^{2}, 2^{2}=$

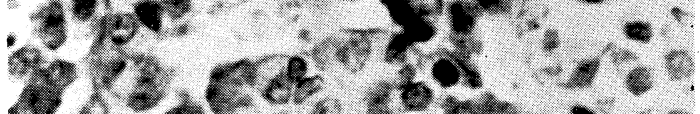

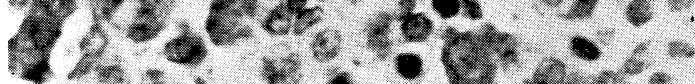

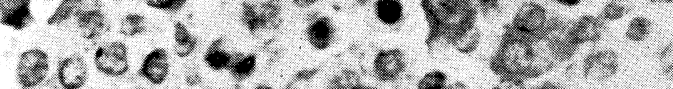

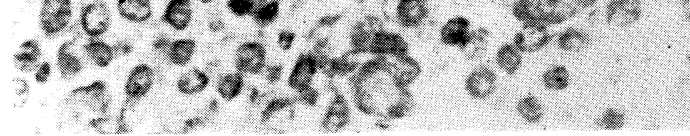

$$
\text { 写真11 EED 2.0 i.u. 㭶与 (PAS ×930) }
$$

PAS (紐胞はみら机方が，ED 投与時に較べてその

数㳉少忘い。
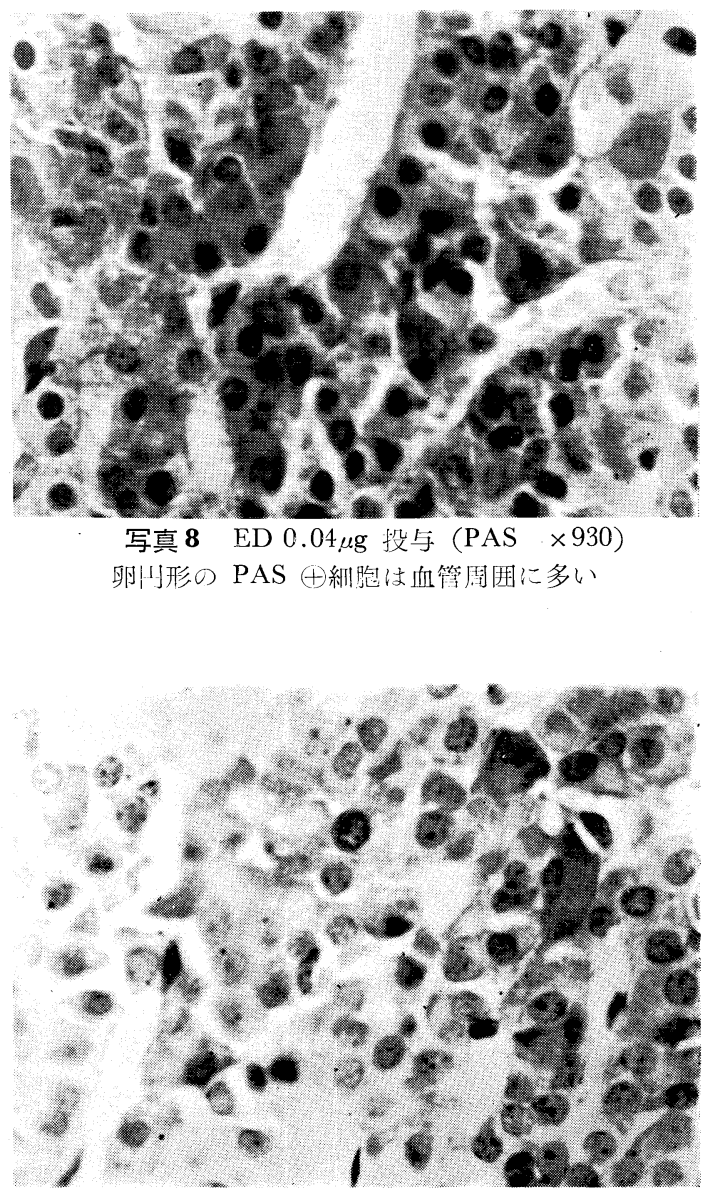

写真10 ET $1 \mu \mathrm{g}$ 投与 $(\mathrm{PAS} \times 930)$

PAS $\oplus$ 紐胞の数は少く核は变形している

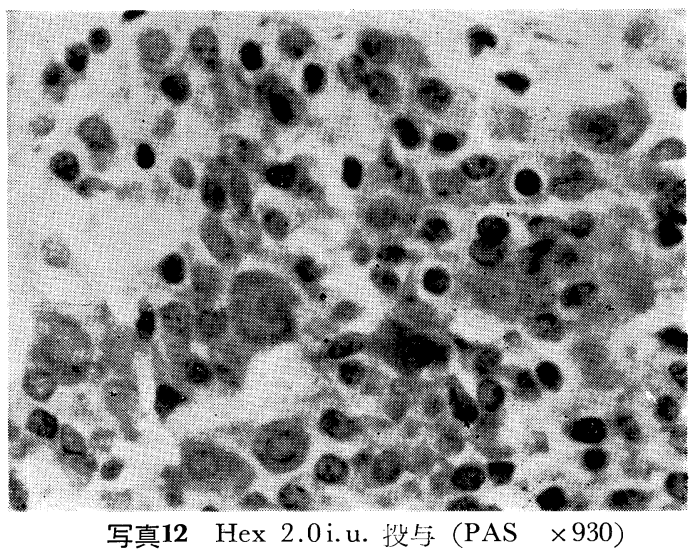

PAS 紐胞はみられるが，数及び陽性度はむしろ低 調 

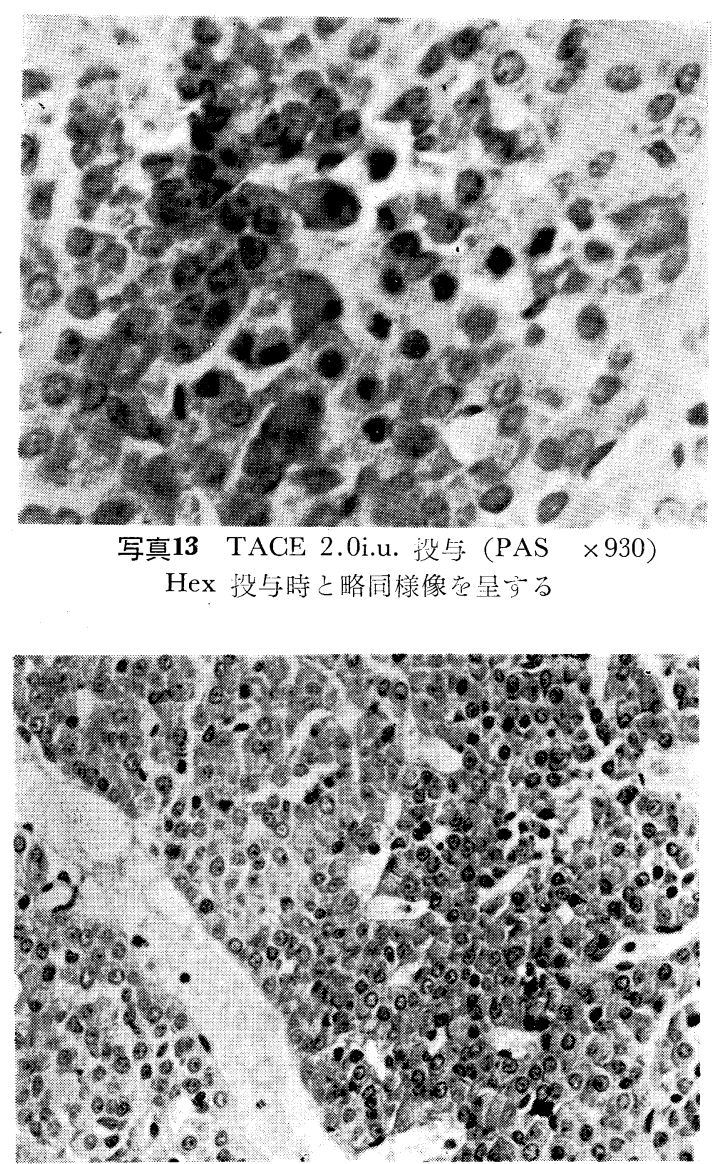

写真15 ED1000 $\mu \mathrm{g}$ 投与. (PAS × 350)

写真 14 と酷似している。血管周囲にも欠如している点 が注目される。

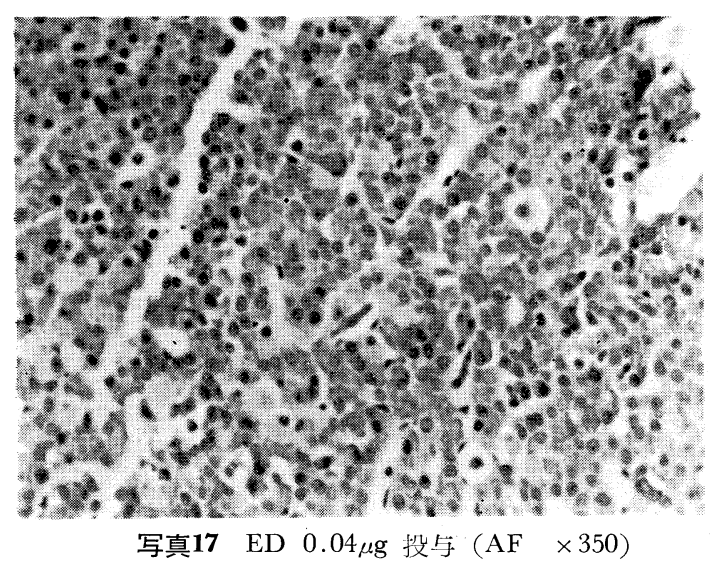

陽性紐胞は血管と注関係なく散在し多角形学呈する

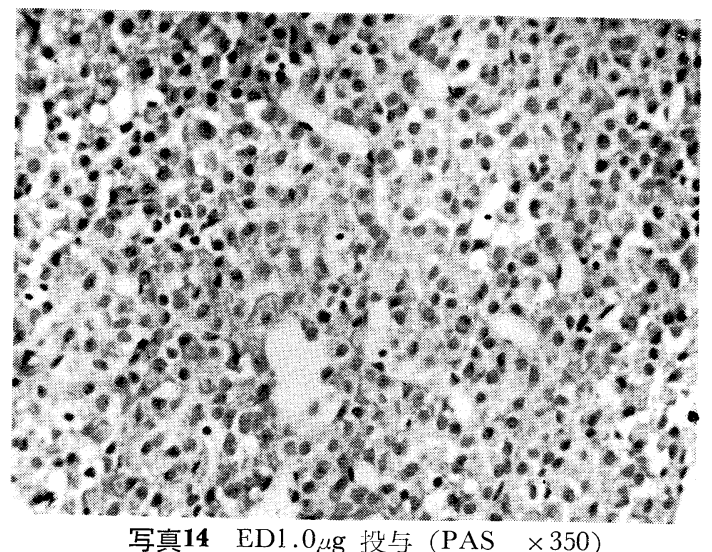

陽性練胞は前葉周辺に於ても卶んごみられない。

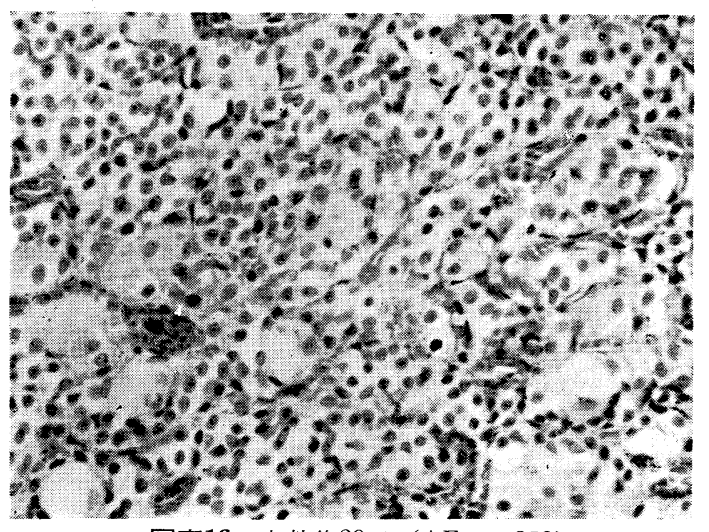

写真16 去勢後 30 日 $($ AF $\times 350)$

上勢紼胞は $\mathrm{AF} \Theta$ 走示。

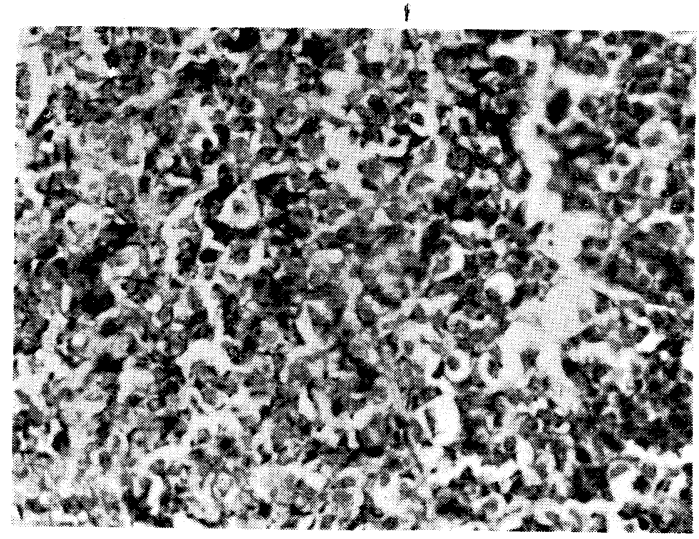

写真18 ED $0.04 \mu \mathrm{g}$ 投与 $(\mathrm{PMG} \times 350)$

$\mathrm{PMG} \oplus$ 絒胞㳉 AZ. BZ 共に2られる。 


\section{木 村 論 文附図（その 4)}

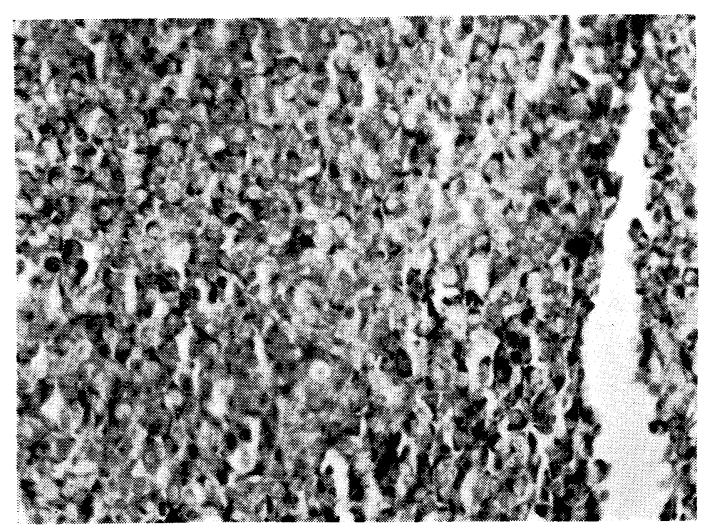

写真19 ED1000 $\mu \mathrm{g}$ 投与 $(\mathrm{PMG} \times 350)$

$\mathrm{BZ}$ の陽性度は殆んぞ消失し，胞体は明調となる

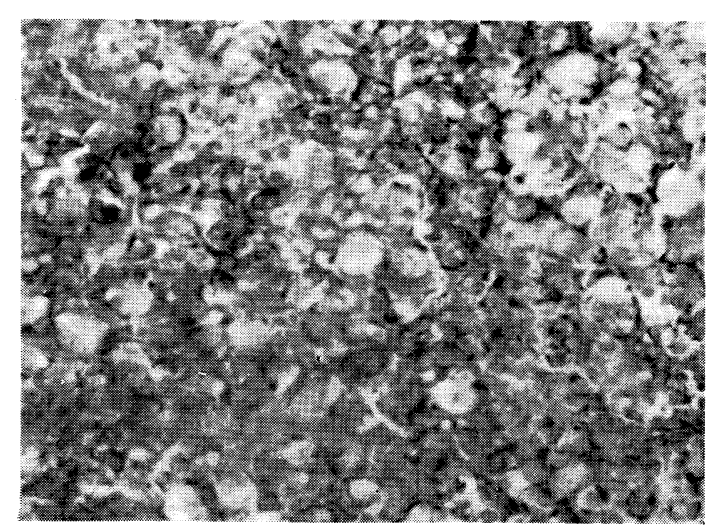

写真 $21 \mathrm{ED} 1000 \mu \mathrm{g}$ 投与 : 去势群 $(\mathrm{PMG} \times 350)$ 去劸細胞の陽㓌度は娍少し胞体は明学い。

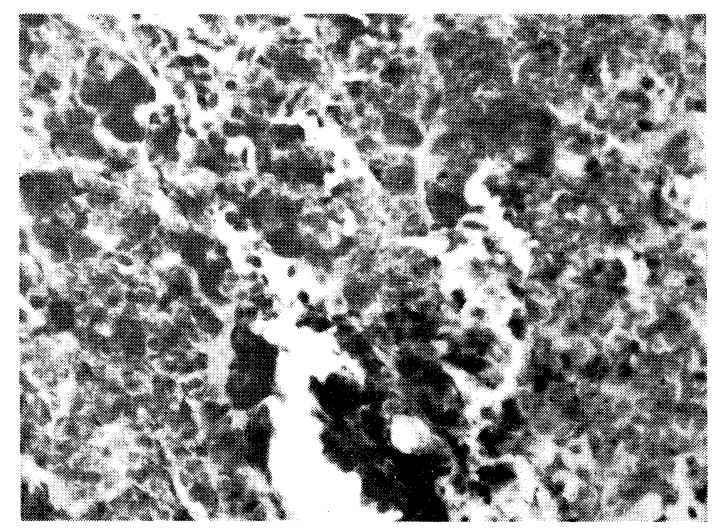

写真20 ED $0.04 \mu \mathrm{g}$ 投与 : 去勢群 $(\mathrm{PMG} \times 350)$ 去勢細胞は陽性度が強い。

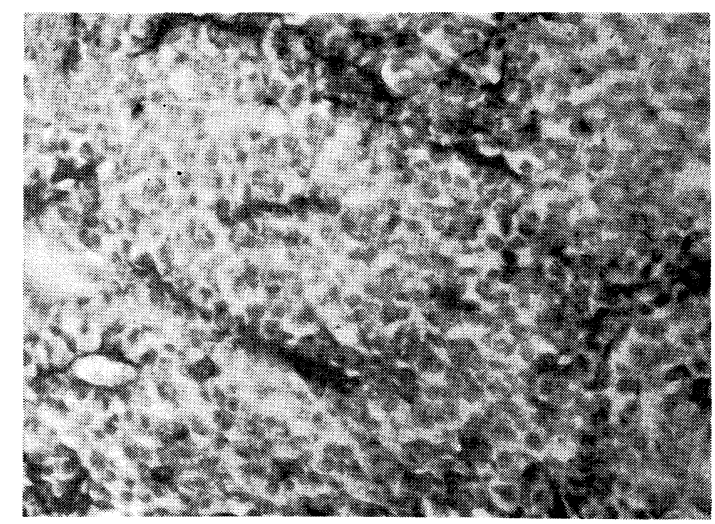

写真22 $\mathrm{ED} 0.02 \mu \mathrm{g}$ 投与 $(\mathrm{Al}-\mathrm{ph} \times 350)$ 陽性䋖胞は周辺に多い.

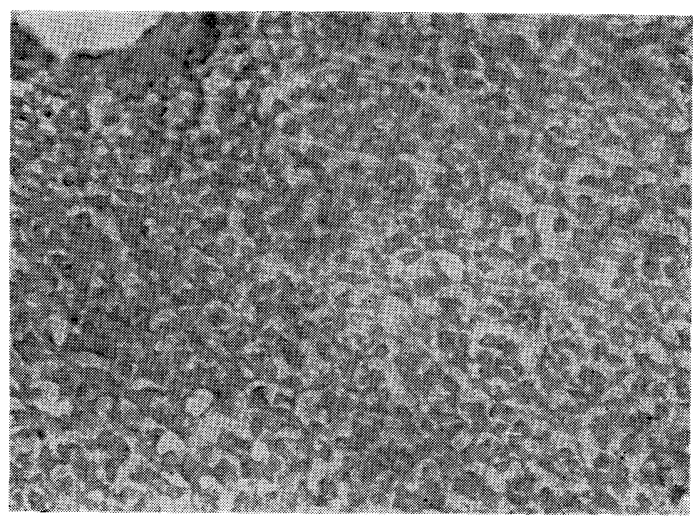

写真23 $\mathrm{ED} 1000 \mu \mathrm{g}$ 投与 $(\mathrm{Al}-\mathrm{ph} \quad \times 350)$

陽性度は殆んぞ消失 